\title{
Geochemistry of the granitoid plutons of the Brookville terrane, Saint John, New Brunswick, and implications for development of the Avalon Zone
}

\author{
G.N. Ebyl and K.L. Currie 2 \\ 1 Department of Earth Sciences, University of Massachusetts, Lowell, Massachusetts 01854, U.S.A \\ ${ }^{2}$ Geological Survey of Canada, 601 Booth Street, Ottawa, Ontario K1A 0E8, Canada
}

\author{
Date Received March 27, 1995 \\ Date Accepted July 3, 1996
}

\begin{abstract}
The Brookville terrane forms a fault-bounded region, underlain mainly by plutonic and high-grade metamorphic rocks, flanked on one side by a typical Avalonian terrane (Caledonia terrane), and separated from a typical Avalonian terrane (Mascarene terrane) on the other side by the Silurian Kingston Dike Complex.

Mafic plutons of the Brookville terrane were derived from a source similar to that of the continental margin basalts of the Coldbrook Group of the Caledonia terrane. Some sialic plutons were probably derived from mixtures of this basaltic component with a component similar to bulk crust. Major element data for most of the plutons fall on smooth curves on Harker diagrams, suggesting that crystal fractionation is the major process controlling the evolution of individual plutons. Trace element modelling indicates that this fractionation was largely due to the removal of hornblende, plagioclase, and alkali feldspar.

The presence of $\mathrm{A}_{2}$-type granites of similar age (ca. $550 \mathrm{Ma}$ ) in the Caledonia terrane (Bonnell Brook), Brookville terrane (Fairville), and Mascarene terrane (Lingley) suggest that these terranes were amalgamated by $550 \mathrm{Ma}$. Subsequent magmatism in the Brookville terrane was characterized by emplacement of plutons typical of continental margin magmatism. This period of magmatism ended with the emplacement of $A_{2}$-type plutons, suggesting that magmatism in the Brookville terrane ceased during post-subduction extension.
\end{abstract}

Le terrane de Brookville forme une région, délimitée par des failles, qui repose principalement sur des roches plutoniques et des roches métamorphiques à haute teneur, accolée d'un côté à un terrane avalonien caractéristique (terrane de Caledonia) et séparée, de l'autre côté, d'un terrane avalonien caractéristique (terrane de Mascarene) par le complexe de filons parallèles silurien de Kingston.

Les plutons mafiques du terrane de Brookville sont provenus d'une source semblable à celle des basaltes de la marge continentale du groupe de Coldbrook du terrane de Caledonia. Certains plutons sialiques sont probablement provenus de mélanges de ce composant basaltique avec un composant analogue à une masse de croute. Les données sur les principaux éléments de la majorité des plutons décrivent des courbes égales et régulières sur les diagrammes de différenciation, ce qui laisse supposer que la cristallisation fractionnée constitue le principal processus régissant l'évolution de chacun des plutons. La modélisation des éléments traces révèle que cette cristallisation était grandement due au retrait de hornblende, de plagioclase et de feldspath alcalin.

La présence de granites de type A-2 d'âge similaire (vers $550 \mathrm{Ma}$ ) dans le terrane de Caledonia (Bonnell Brook), le terrane de Brookville (Fairville) et le terrane de Mascarene (Lingley) permet de supposer que ces terranes se sont fusionnés vers $550 \mathrm{Ma}$. Le magmatisme subséquent dans le terrane de Brookville a été caractérisé par l'intrusion de plutons typiques d'un magmatisme de la marge continentale. Cette période de magmatisme a pris fin avec une intrusion de plutons de type A-2, ce qui amène à penser que le magmatisme à l'intérieur du terrane de Brookville a cessé au cours de l'extension postérieure à la subduction.

[Traduit par la rédaction]

\section{INTRODUCTION}

The Avalon Zone (Williams, 1979), extending from eastern Newfoundland to southeastern New England (Fig. 1), is characterized by little metamorphosed, upper Precambrian volcanic-sedimentary sequences, and Cambrian strata with an Acado-Baltic fauna. Absence of these elements makes identification of deeper levels of Avalonian terranes a difficult and controversial task, particularly since the Avalon Zone is dissected by an extensive network of longitudinal faults. This lack of agreement on the definition of Avalonian terranes implies a lack of agreement on tectonic and crustal evolution of the Avalon Zone and its relationship to the early
Paleozoic Iapetus Ocean. Two models have been advanced. (i) The Avalon Zone consists of a mosaic of exotic terranes assembled in Silurian and later time by transcurrent and/or thrust motions (Barr and White, 1988; Barr and Raeside, 1989; Barr et al., 1994). (ii) The Avalon Zone consists of different structural levels of the same terrane, or related terranes, assembled in late Precambrian time, juxtaposed by Silurian and later fault motions (Dallmeyer et al., 1990; Keppie et al., 1991; Nance and Dallmeyer, 1993). Southern New Brunswick plays a key role in this debate, because diverse terranes of the Avalon Zone have been well mapped (Currie, 1987; Barr and White, 1989) and regional chemical and isotopic data have been reported (Whalen et al., 1994). We 

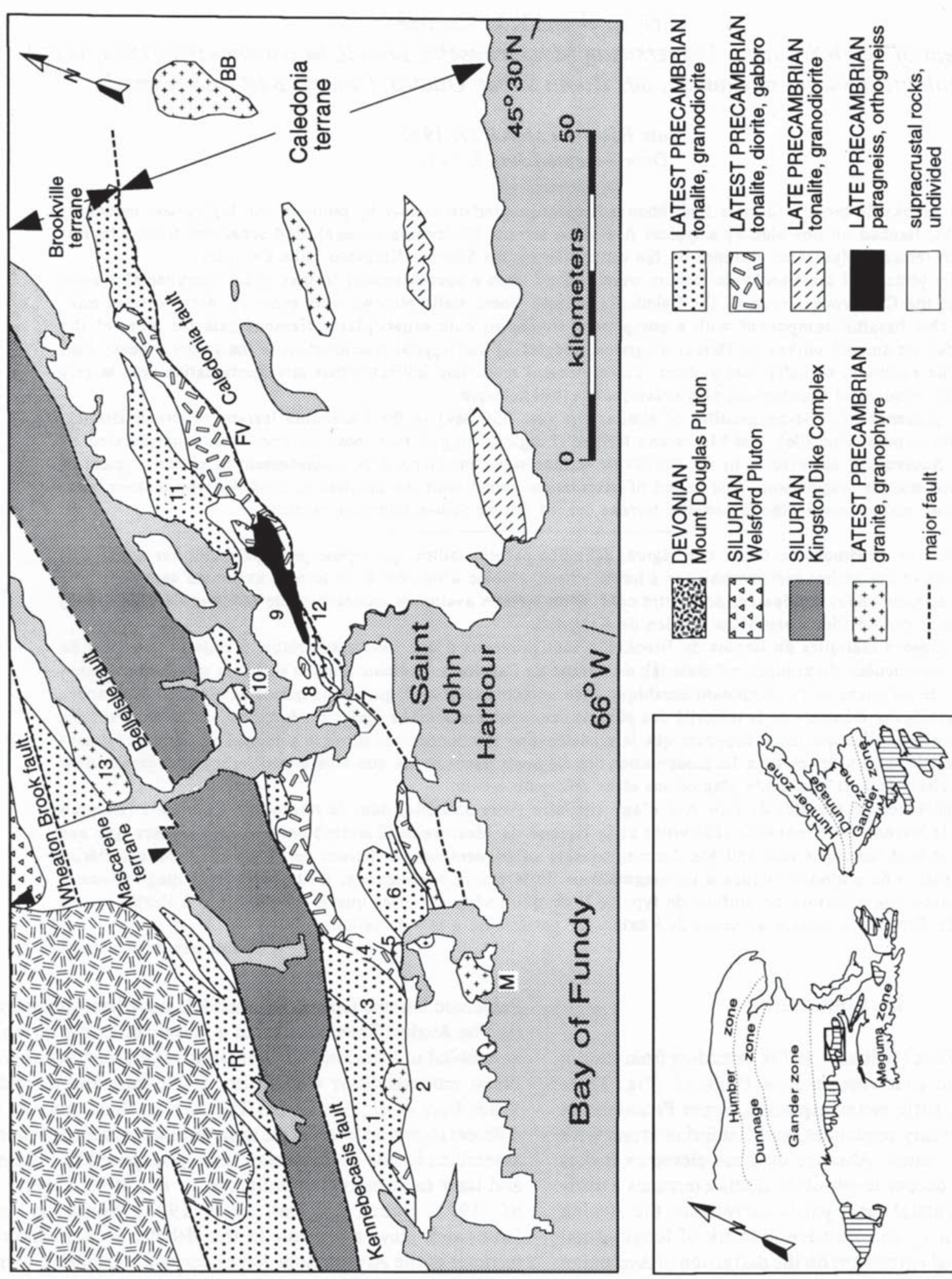

늘 ฮิ

हิं ติ

ชึ चु

क出的

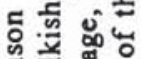

品芒兽。

"II ร 융

-으릉으

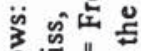

웡료

๓ $\triangleq$

उ

응

空跑

"

क्ष

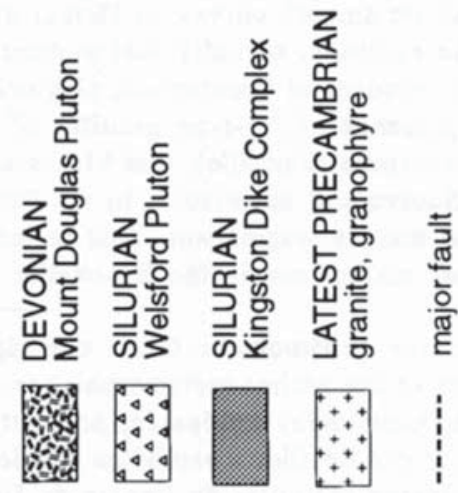

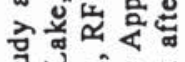

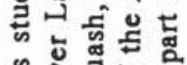

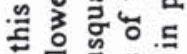

.

证之次

ㄴ. 11.0

压 $\infty$ 兘

है을

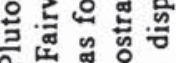

a.

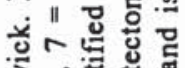

政

要总

링ㅎㅇ

ต

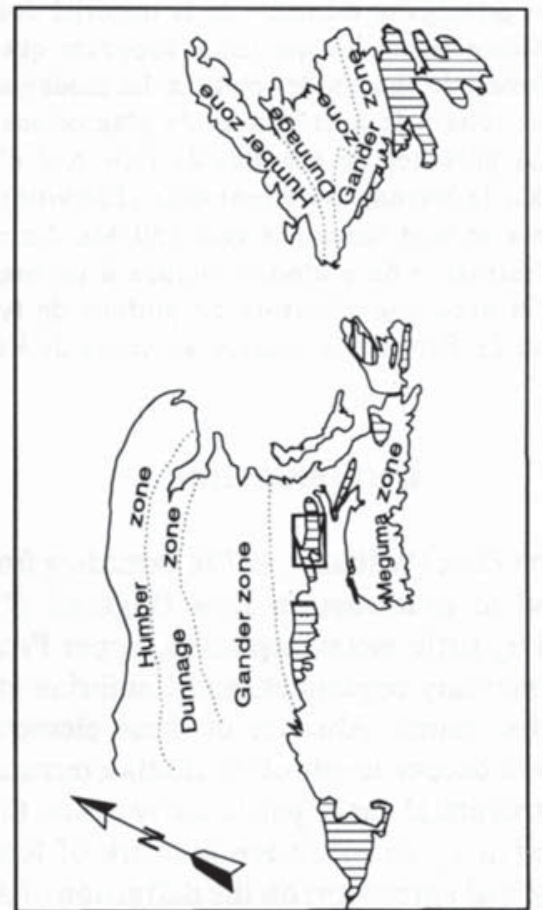

乙远苍品

태응 웡

느. ㄷ․․․

호웛

ธิ

잉

들 突

영영

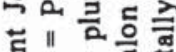

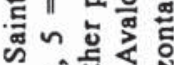

की

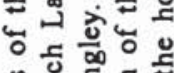

능. 동

잉

에 $\stackrel{2}{0}$

过芒完

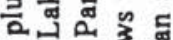

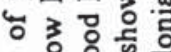

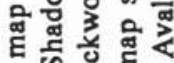

¿"

包 II

츨

क्ष

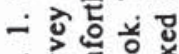

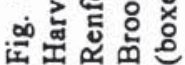


report here new chemical data bearing on the origin of the Brookville terrane near Saint John, New Brunswick.

\section{Geologic Setting}

Four distinct tectono-stratigraphic belts have been recognized in southern New Brunswick, all of which have traditionally been included in the Avalon Zone or terrane (Fig. 1). These are, from southeast to northwest, the Caledonia terrane (Barr and White, 1989, 1991), the Brookville terrane (Barr and White, 1989, 1991), the Kingston Complex (Currie, 1984; Eby and Currie, 1993; Nance and Dallmeyer, 1993), and the Mascarene terrane (Fyffe and Fricker, 1987).

The Caledonia terrane consists of rocks of two distinct ages (Bevier and Barr, 1990; Barr et al., 1994; Barr and White, 1996). The older (ca. 635-600 Ma) group of volcanic and sedimentary rocks (Broad River Group) is regionally metamorphosed (greenschist facies). The associated plutonic units (ca. 625-615 Ma) are calc-alkaline and were emplaced during continental margin subduction (Barr and White, 1988). The younger (ca. 560-550 Ma) group of volcanic and sedimentary rocks (Coldbrook Group) is unmetamorphosed and is intruded by a ca. 560 to $550 \mathrm{Ma}$ suite of bimodal plutons, of which Bonnell Brook is the largest, typical of post-orogenic extension (Barr and White, 1988). These units are overlain by shallow to deep-water sedimentary rocks of the Cambrian to Ordovician Saint John Group that contain AcadoBaltic fauna (Tanoli and Pickerill, 1988). The Caledonia terrane is separated from the Brookville terrane by the CaledoniaClover Hill fault (Fig. 1).

The Brookville terrane has three major components: the Green Head Group, the Brookville Gneiss, and numerous dioritic to granitic plutons. The Green Head Group comprises a lower carbonate and quartzite sequence (Ashburn Formation), interpreted to have been deposited on a passive continental margin, and an upper turbidite sequence (Martinon Formation), mainly metasiltstone but locally containing large clasts of Ashburn Formation. The Greenhead Group is everywhere in faulted contact with the Brookville Gneiss, which consists of low-pressure, tonalitic to granodioritic orthogneiss, amphibolite, and paragneiss with minor marble and quartzite (White and Barr, 1996). Detrital zircon from the paragneiss gives a maximum depositional age of ca. $640 \mathrm{Ma}$ for the protolith, and zircon from the orthogneiss yields a crystallization age of ca. $605 \mathrm{Ma}$ (Bevier et al., 1990; Dallmeyer et al., 1990). The age of amphibolite facies metamorphism is interpreted to be ca. 564 to $545 \mathrm{Ma}$ (Bevier et al., 1990; Dallmeyer et al., 1990; Nance and Dallmeyer, 1994). The Green Head Group and Brookville Gneiss are intruded by calc-alkalic, I-type granitoid rocks, typical of those that characterize continental margin subduction zones (Dickson, 1983; White et al., 1990; White, 1995). Although they broadly resemble the ca. 625 to 615 Ma plutons of the Caledonia terrane, they are significantly younger with $\mathrm{U}-\mathrm{Pb}$ zircon and titanite crystallization ages from ca. 550 to $538 \mathrm{Ma}$ and hornblende and biotite ${ }^{40} \mathrm{Ar} /{ }^{39} \mathrm{Ar}$ cooling(?) ages as young as ca. $510 \mathrm{Ma}$ (White et al., 1990; Bevier et al., 1991; Currie and Hunt, 1991; Dallmeyer and Nance, 1992; White, 1995).
West of Musquash Harbour, felsic volcanic rocks apparently consanguineous with high level plutons give a U-Pb zircon age of $555 \mathrm{Ma}$ (Zain-Eldeen et al., 1991).

The Kingston Complex comprises sheeted mafic and felsic dikes with minor related volcanic and plutonic rocks. Geochronological and geochemical data indicate that these units were emplaced in an Early Silurian sinistral transtensional setting (Doig et al., 1990; Eby and Currie, 1993; McLeod et al., 1994). The complex was metamorphosed to greenschist - lower amphibolite grade and deformed during Late Silurian to Early Devonian dextral transpression (Nance and Dallmeyer, 1993). The Kingston Complex is separated from the Brookville terrane by the Kennebecasis fault (Fig. 1), which has a major mylonite zone at its southwestern end (Pocologan mylonite zone).

The Mascarene terrane (Fyffe and Fricker, 1987) includes a suite of calc-alkaline latest Proterozoic plutons and minor, cogenetic felsic volcanic rocks overlain by Lower Cambrian to Upper Ordovician volcanic and sedimentary units, that locally contain Acado-Baltic fauna (Hayes and Howell, 1937). Silurian sedimentary and volcanic rocks overlie these units (McLeod et al., 1994). The Mascarene terrane is faulted against the Kingston Complex, across the Bellisle Fault, along its southeastern margin.

\section{Petrography of SAMPLed Units}

Most plutons of the Brookville terrane consist of quartz diorite, tonalite, granodiorite, and monzogranite (nomenclature of Streckeisen, 1976). A brief description of the petrography of the various units sampled in this study is given below. Pluton names (Fig. 1 and Table 1) conform to the terminology of Hayes and Howell (1937), supplemented where necessary by subsequent mapping (Currie, 1987; White et al., 1990; White, 1995). Also included in these descriptions is the Lingley Pluton, which intrudes the Mascarene terrane but may be of the same age as Brookville terrane magmatism.

\section{Hanson Stream Pluton}

The Hanson Stream Pluton (Fig. 1, \#1), the largest pluton west of the Saint John River, forms a homogeneous mass of gray, medium to coarse grained, unfoliated, hornblendebiotite granodiorite to monzogranite. Rounded dioritic xenoliths are common. The Hanson Stream Pluton is in sharp contact with the Shadow Lake Pluton and is intruded by the Harvey Hill Pluton. Dallmeyer and Nance (1992) obtained a ${ }^{36} \mathrm{Ar} /{ }^{40} \mathrm{Ar}$ versus ${ }^{40} \mathrm{Ar} /{ }^{39} \mathrm{Ar}$ isotope correlation age of $518 \mathrm{Ma}$ for hornblende from the Hanson Stream Pluton. The pluton was sampled in road-cuts along Highway 1.

\section{Harvey Hill Pluton}

The Harvey Hill Pluton (Fig. 1, \#2) forms a sub-circular mass of fine to medium grained, locally porphyritic, red granite and granophyre. Brown to olive-green biotite (often altered to chlorite) is the only significant mafic phase. Lo- 
Table 1. Ages for Saint John district plutons.

\begin{tabular}{|c|c|c|c|c|}
\hline Pluton & $\begin{array}{l}\text { Map } \\
\text { Ref. }\end{array}$ & Age (Ma) & Method & Reference \\
\hline Hanson Stream & 1 & $518 \pm 2$ & $\mathrm{Ar} / \mathrm{Ar}$ & Dallmeyer and Nance (1992) \\
\hline Harvey Hill & 2 & $<518$ & Contact & Intrudes Hanson Stream \\
\hline Shadow Lake & 3 & 527 & $\mathrm{Ar} / \mathrm{Ar}$ & White (1995) \\
\hline Perch Lake & 4 & $526 \pm 2$ & $\mathrm{Ar} / \mathrm{Ar}$ & Dallmeyer and Nance (1992) \\
\hline Prince of Wales & 5 & $<526$ & Contact & Intrudes Perch Lake \\
\hline Ludgate Lake & 6 & 546 & $\mathrm{U} / \mathrm{Pb}$ zircon & White (1995) \\
\hline Fairville & 7 & $\begin{array}{l}548 \\
547 \pm 1\end{array}$ & $\begin{array}{l}\mathrm{U} / \mathrm{Pb} \text { zircon } \\
\mathrm{Ar} / \mathrm{Ar}\end{array}$ & $\begin{array}{l}\text { White (1995) } \\
\text { Dallmeyer and Nance (1992) }\end{array}$ \\
\hline Mayflower Lake & 8 & 540 & Not reported & Whalen et al. (1994) \\
\hline Brookville & 9 & $605 \pm 3$ & $\mathrm{U} / \mathrm{Pb}$ zircon & Bevier et al. (1990) \\
\hline Milkish Head & 10 & $520 \pm 2$ & $\mathrm{Ar} / \mathrm{Ar}$ & Dallmeyer and Nance (1992) \\
\hline Renforth & 11 & 511 & $\mathrm{Ar} / \mathrm{Ar}$ & White (1995) \\
\hline Rockwood Park & 12 & $\begin{array}{l}538 \pm 1 \\
529 \pm 2\end{array}$ & $\begin{array}{l}\mathrm{U} / \mathrm{Pb} \text { zircon } \\
\mathrm{Ar} / \mathrm{Ar}\end{array}$ & $\begin{array}{l}\text { White et al. (1990) } \\
\text { Dallmeyer and Nance (1992) }\end{array}$ \\
\hline Lingley & 13 & 555 & $\begin{array}{l}\text { Correlation } \\
\text { Ragged Falls }\end{array}$ & Currie (1987) \\
\hline Musquash & $\mathbf{M}$ & $550 \pm 15$ & $\mathrm{U} / \mathrm{Pb}$ zircon & Currie and Hunt (1991) \\
\hline Ragged Falls & RF & $555 \pm 2$ & $\mathrm{U} / \mathrm{Pb}$ zircon & McLood et al. (1994) \\
\hline French Village & FV & $\begin{array}{l}538 \pm 1 \\
539 \pm 2\end{array}$ & $\begin{array}{l}\mathrm{U} / \mathrm{Pb} \text { zircon } \\
\mathrm{Ar} / \mathrm{Ar}\end{array}$ & $\begin{array}{l}\text { Bevier et al. (1990) } \\
\text { Dallmeyer and Nance (1992) }\end{array}$ \\
\hline $\begin{array}{l}\text { Bonnell Brook } \\
\text { Coldbrook Group } \\
\text { Broad River Group }\end{array}$ & BB & $\begin{array}{l}550 \pm 1 \\
554-559 \\
613-618\end{array}$ & $\begin{array}{l}\mathrm{U} / \mathrm{Pb} \text { zircon } \\
\mathrm{U} / \mathrm{Pb} \text { zircon } \\
\mathrm{U} / \mathrm{Pb} \text { zircon }\end{array}$ & $\begin{array}{l}\text { Bevier and Barr (1990) } \\
\text { Barr et al. (1994) } \\
\text { Barr et al. (1994) }\end{array}$ \\
\hline
\end{tabular}

cally, primary muscovite and garnet are found. Zircon and allanite occur as accessory phases. The Harvey Hill Pluton grades to aphanitic porphyritic phases of epizonal or subvolcanic character, and intrudes the Hanson Stream and Shadow Lake plutons. The age of the Harvey Hill Pluton is uncertain, but it must be younger than the Hanson Stream and Shadow Lake plutons (ca. $518 \mathrm{Ma} \mathrm{Ar} / \mathrm{Ar}$ age). The pluton was sampled in road cuts along Highway 1 and on side roads.

\section{Shadow Lake Pluton}

The Shadow Lake Pluton (Fig. 1, \#3) consists of poorly foliated, gray, medium to coarse grained tonalite and granodiorite, locally grading to quartz diorite, all with hornblende and biotite as the dominant mafic minerals. Chlorite and epidote occur in patches. The unit contains numerous tonalitic to dioritic enclaves. Contact with the Perch Lake Pluton to the east is not exposed. White (1995) reports ${ }^{40} \mathrm{Ar} /$ ${ }^{39} \mathrm{Ar}$ ages of ca. $527 \mathrm{Ma}$ for the Shadow Lake Pluton. The pluton was sampled from road-cuts along Highway 1.

\section{Perch Lake Pluton}

The Perch Lake Pluton (Fig. 1, \#4) outcrops immediately west of the Ludgate Lake Pluton and is separated from it by a narrow septum of hornfels and an inclusion-rich zone.
The pluton consists dominantly of medium grained, near massive tonalite to granodiorite with abundant, fine to coarse grained dioritic xenoliths. Hornblende is abundant, but is locally replaced by biotite and chlorite. Epidote occurs in small veinlets and patches. Dallmeyer and Nance (1992) report a ${ }^{36} \mathrm{Ar} /{ }^{40} \mathrm{Ar}$ versus ${ }^{40} \mathrm{Ar} /{ }^{39} \mathrm{Ar}$ isotope correlation age of $526 \mathrm{Ma}$ for a sample, whose geographic location indicates it came from the Perch Lake Pluton. The pluton was sampled in road cuts along Highway 1 and on large bare outcrops south of the highway.

\section{Prince of Wales Pluton}

The Prince of Wales Pluton (Fig. 1, \#5) consists of hypidiomorphic, equigranular to porphyritic, pink monzogranite to syenogranite. Locally the unit is foliated. Biotite is the only significant mafic phase and epidote is sparse. Locally tonalitic enclaves are found. The Prince of Wales Pluton intrudes the Perch Lake and Ludgate Lake plutons.

\section{Ludgate Lake Pluton}

The Ludgate Lake Pluton (Fig. 1, \#6) consists mainly of medium grained, fractured granodiorite with lesser tonalite. Hornblende and biotite are present in variable amounts. Epidote and chlorite occur in patches. There are numerous rounded 
dioritic xenoliths. The Ludgate Lake Pluton intrudes the Martinon Formation of the Green Head Group at its northwest end, with development of hornfels in the Martinon Formation. At its southwest end, the pluton is separated from the Perch Lake Pluton by a narrow septum of hornfels probably derived from the Martinon Formation. White (1995) reports U-Pb zircon and titanite ages of $\mathrm{ca} .546 \mathrm{Ma}$ for this pluton. The pluton was sampled in road-cuts on Highway 1.

\section{Fairville Pluton}

The Fairville Pluton (Fig. 1, \#7) consists of near massive, two-feldspar, medium to coarse grained, hornblende granodiorite to monzogranite with accessory apatite and zircon. Epidote-chlorite alteration is common but minor in amount. Locally, the pluton contains xenoliths of amphibolite, gneiss and marble elongated along the northeast-southwest tectonic grain. The Fairville Pluton intrudes the Green Head Group, and is intruded by the Rockwood Park Pluton. White (1995) reports a U-Pb zircon age of $\mathrm{ca}$. $548 \mathrm{Ma}$ for this pluton.

\section{Mayflower Lake Pluton}

The Mayflower Lake Pluton (Fig. 1, \#8) forms a small elliptical body elongate along tectonic grain and composed of medium to coarse grained, fractured hornblende quartz diorite and hornblende tonalite with minor biotite. Epidote is common and chlorite is locally abundant. The pluton intrudes the Green Head Group. Whalen et al. (1994) report an age of $540 \mathrm{Ma}$ for this pluton, which was sampled in road cuts along Sandy Point Road.

\section{Brookville Gneiss}

The Brookville Gneiss (Fig. 1, \#9) is dominantly a biotite-cordierite-feldspar-bearing paragneiss (locally migmatitic), with minor sillimanite and andalusite. Associated with the paragneiss are minor, calc-silicate and marble layers and rare feldspar-rich quartzites. Granodioritic to tonalitic orthogneiss and rare amphibolite form sheets in the paragneiss. Muscovite-tourmaline-bearing aplites and pegmatites crosscut the gneiss and have a ${ }^{40} \mathrm{Ar} /{ }^{39} \mathrm{Ar}$ muscovite plateau age of ca. $510 \mathrm{Ma}$ (Dallmeyer and Nance, 1992). The gneiss is in fault contact with marble and quartzite (Green Head Group) on both sides, and is intruded by several younger plutons. The Brookville Gneiss contains abundant retrograde chlorite and epidote, although locally fresh cordierite is still preserved, as well as rare joint fillings and veins of epidote. The orthogneiss component of the Brookville Gneiss was emplaced at $605 \mathrm{Ma}$ (Bevier et al., 1990; Dallmeyer et al., 1990). The gneiss was sampled in a large quarry near its northern end, which provides a cross-section across the unit, and from several outcrops further to the southwest.

\section{Milkish Head Pluton}

The Milkish Head Pluton (Fig. 1, \#10) consists of coarse grained, equigranular, slightly foliated, biotite granite and medium grained, biotite granodiorite, well exposed in bluffs on the northwest shore of Kennebecasis Bay. The alkali feldspars are perthitic microcline. Primary biotite is largely replaced by chlorite that is locally deformed. Veinlets of epidote occur in some specimens, but in general epidote is sparse in this unit. Elongate dioritic xenoliths occur locally. The Milkish Head Pluton is faulted against Carboniferous strata. Dallmeyer and Nance (1992) report a ${ }^{36} \mathrm{Ar} /{ }^{40} \mathrm{Ar}$ versus ${ }^{40} \mathrm{Ar} /{ }^{39} \mathrm{Ar}$ isotope correlation age of $520 \mathrm{Ma}$ for this pluton. The pluton was sampled in rock cuts at the ferry landing and access roads leading to the landing.

\section{Renforth Pluton}

The Renforth Pluton (Fig. 1, \#11) forms a thin elongate mass along the southeast shore of Kennebecasis Bay and was mapped as a continuation of the Milkish Head Pluton on the northwest side of the bay (Currie, 1987; White et al., 1990). Chemical data indicate that the two plutons are distinct. The Renforth Pluton consists of medium to coarse grained, hornblende quartz diorite and hornblende-biotite tonalite. Mafic minerals are variably altered to chlorite and carbonate, but epidote is rare, and locally the rock is relatively unaltered. Fine grained, rounded dioritic xenoliths occur throughout the pluton. The Renforth Pluton intrudes the Green Head Group, and is in fault contact with the Cambrian Saint John Group which contains Acado-Baltic fauna. White (1995) reports a ${ }^{40} \mathrm{Ar} /{ }^{39} \mathrm{Ar}$ hornblende age of $\mathrm{ca}$. $511 \mathrm{Ma}$ for this pluton. The pluton was sampled along the shore of Kennebecasis Bay.

\section{Rockwood Park Pluton}

The Rockwood Park Pluton (Fig. 1, \#12) consists of moderately to strongly foliated, gray, medium grained, granodiorite gradational to tonalite. Both phases were sampled for this study. Brown to green biotite and hornblende (locally altered to chlorite and epidote) are the dominant mafic phases, and veinlets of epidote and chlorite are common. Dioritic inclusions elongate on the foliation occur 10cally. The Rockwood Park Pluton intrudes the Green Head Group. A U-Pb zircon age of $538 \mathrm{Ma}$ (White et al., 1990) and ${ }^{40} \mathrm{Ar} /{ }^{39} \mathrm{Ar}$ hornblende and biotite ages of ca. 538 and 511 Ma respectively (White, 1995) have been determined for this pluton.

\section{Lingley Pluton}

The Lingley Pluton (Fig. 1, \#13) consists of quartz feldspar porphyry, with quartz and alkali feldspar in a fine grained quartz-feldspar groundmass. Locally the quartz phenocrysts have been broken. Chloritic alteration is common, and the rock is cut by carbonate and quartz veinlets. Epidote was not observed in thin section. The Lingley Pluton is faulted on the north against a coarse grained, hornblende-biotite granodiorite, and on the south against the Kingston Complex. The pluton is probably cogenetic with sialic volcanic strata at its southwest end. The Lingley Pluton has not been dated, but on the basis of field relations it may be the same age as the Ragged Falls Pluton (555 Ma U/Pb zircon age; 
McL eod et al., 1994), with which it may be connected at depth. The pluton was sampled in road cuts along Highway 102 , and cuts along the parallel, abandoned railway right of way.

\section{Analytical methods}

Approximately $1 \mathrm{~kg}$ size samples were collected from surface outcrops. Epidote veining is common in many of the units and an effort was made to avoid these veins during sample collection. Slabs were cut from the samples, weathered material trimmed from the slabs, and slabs were then reduced to chips that were subsequently cleaned in distilled water and acetone. Reduction to powder was done by first crushing in a jaw crusher with hardened steel plates, then reducing to fine, sand sized material in a rotary pulverizer with ceramic plates, and finally grinding an aliquot of this material to a powder in a ceramic mortar and pestle.

Major elements were determined by atomic absorption spectroscopy using the acid decomposition method of Bernas (1968). Replicate analyses of USGS standard rocks indicates a precision of $\pm 2 \%$ for all major elements except Ca $( \pm 5 \%) . \mathrm{Fe}^{2+}$ was determined by titration (Wilson, 1955). $\mathrm{V}, \mathrm{Cr}, \mathrm{Ni}, \mathrm{Cu}, \mathrm{Zn}, \mathrm{Rb}, \mathrm{Sr}, \mathrm{Ba}, \mathrm{Y}, \mathrm{Nb}, \mathrm{Pb}, \mathrm{Zr}$ and $\mathrm{Ga}$ were determined by XRF on 10 gram pressed powders. Estimated precision, based on replicate analyses of USGS standards, is better than $\pm 5 \%$. Sc, Co, Cs, $\mathrm{La}, \mathrm{Ce}, \mathrm{Nd}, \mathrm{Sm}, \mathrm{Eu}, \mathrm{Gd}, \mathrm{Tb}$, $\mathrm{Tm}, \mathrm{Yb}, \mathrm{Lu}, \mathrm{Hf}, \mathrm{Ta}$, Th and $\mathrm{U}$ were determined by INAA. Except for Cs and Gd ( $\pm 10 \%)$, estimated precision and accuracy for these elements is better than $\pm 5 \%$. The analytical data are reported in Table 2.

\section{Geochemistry}

\section{Major Elements}

Chemically, the plutons of the Brookville terrane are subalkaline (Fig. 2) and calc-alkaline (Fig. 3). In terms of $\mathrm{Al}_{2} \mathrm{O}_{3}, \mathrm{FeO}_{\mathrm{t}}, \mathrm{MnO}$ and $\mathrm{CaO}$, the entire suite of plutons forms smooth curves on Harker diagrams. The same is essentially true for $\mathrm{TiO}_{2}$ and $\mathrm{MgO}$ with the exception of the Fairville Pluton, which has higher $\mathrm{TiO}_{2}$ and lower $\mathrm{MgO}$ relative to other plutons of similar silica content (Fig. 4), and the Harvey Hill and Lingley (intruded into the Mascarene terrane) plutons, which have very low $\mathrm{MgO}$ contents. $\mathrm{Na}_{2} \mathrm{O}$ (not shown) tends to be constant across the entire suite whereas $\mathrm{K}_{2} \mathrm{O}$ (Fig. 5) is variable. Some of the scatter in the $\mathrm{K}_{2} \mathrm{O}$ probably results from alteration, but there are two discrete groups or trends in terms of $\mathrm{K}_{2} \mathrm{O}$. The first, relatively enriched in $\mathrm{K}_{2} \mathrm{O}$ consists of the Perch Lake, Fairville, Milkish Head, Prince of Wales and Harvey Hill plutons. The second, relatively depleted $\mathrm{K}_{2} \mathrm{O}$ group consists of the Mayflower Lake, Renforth, Ludgate Lake, Hanson Stream and Lingley plutons. In terms of $\mathrm{K}_{2} \mathrm{O}$, the Milkish Head and Renforth plutons clearly differ from each other. The Shadow Lake Pluton contains a medium grained diorite phase, which plots in the low $\mathrm{K}_{2} \mathrm{O}$ group, and a coarse grained granodiorite phase, which plots in the high $\mathrm{K}_{2} \mathrm{O}$ group. The Lingley Pluton has undergone deformation on faults bounding the Kingston Complex. Eby and Currie (1993) noted extensive loss of $\mathrm{K}_{2} \mathrm{O}$ and $\mathrm{Rb}$ in rhyolitic and granitic rocks of the Kingston Complex. Contemporary alkali loss in the Lingley Pluton is therefore probable. Lingley samples plot either near the $0.5 \mathrm{Kbar}$ minimum or well into the quartz-rich side of the Quartz-Alkali FeldsparPlagioclase phase diagram (Tuttle and Bowen, 1958). Quartz veins occur in the Lingley and this pluton may have undergone both alkali loss and silica addition.

\section{Trace Elements}

Most of the trace elements show regular variation with $\mathrm{SiO}_{2}$. Sc declines regularly with increasing $\mathrm{SiO}_{2}$ (Fig. 6). Since hornblende is the common ferromagnesian silicate in the mafic members of the suite, this trend most likely reflects the fractional crystallization of hornblende. $\mathrm{Ni}$ is generally low in all units (Fig. 6), with the exception of the Mayflower Lake and Perch Lake plutons and single samples from the Shadow Lake (quartz diorite) and Milkish Head (granodiorite) plutons. Ni variation could result from slightly different sources or from variable mixtures of crustal and mantlederived materials.

Plagioclase and alkali feldspar are major minerals likely to have fractionated from all the magmas. The $\mathrm{Eu} / \mathrm{Eu}^{*}$ ratio (observed $\mathrm{Eu}$ abundance/Eu abundance calculated from the chondrite normalized curves) is a useful petrogenetic indicator because it is sensitive to the fractionation of feldspar minerals. The $\mathrm{Eu} / \mathrm{Eu}^{*}$ ratio is plotted versus $\mathrm{Ba}, \mathrm{Sr}, \mathrm{Nb}$ and $\mathrm{Zr}$ on Figure $7 \mathrm{a}$ and $\mathrm{b}$, together with crystallization vectors ( $20 \%$ fractionation) for hornblende, plagioclase and alkali feldspar, the minerals most likely to crystallize from these magmas. The Lingley, Prince of Wales, and Harvey Hill plutons are the most evolved granitoids in terms of $\mathrm{Eu} / \mathrm{Eu}^{*}$ and have generally high $\mathrm{Nb}$ and $\mathrm{Zr}$ contents but low $\mathrm{Sr}$, consistent with their evolved character. Sr decreases regularly, as would be expected during fractional crystallization of alkali feldspar and plagioclase. The Lingley Pluton has an anomalous trend of increasing $\mathrm{Ba}$ with decreasing $\mathrm{Eu} / \mathrm{Eu}^{*}$, which could be explained by fractionation of plagioclase in the absence of alkali feldspar. However, a magma of this composition would co-crystallize alkali feldspar under all probable conditions, thus a more likely explanation is that the alkalis have been post-magmatically redistributed. The Mayflower Lake quartz diorite-tonalite has the highest $\mathrm{Sr}$ and lowest $\mathrm{Ba}$ of any of the plutons and shows trends on the $\mathrm{Ba}$ and $\mathrm{Sr}$ versus $\mathrm{Eu} / \mathrm{Eu}^{*}$, which can be generated by co-crystallizing plagioclase and hornblende. The Ludgate Lake, Hanson Stream and Renforth plutons tend to plot together on these diagrams as they do on the $\mathrm{K}_{2} \mathrm{O}-\mathrm{SiO}_{2}$ diagram. The Fairville Pluton is distinct from all of the other units in its relatively higher $\mathrm{Ba}, \mathrm{Nb}$ and $\mathrm{Zr}$.

\section{Rare Earth Elements}

Chondrite normalized REE plots for Harvey Hill, Lingley, and Prince of Wales (Fig. 8) are broadly similar. Harvey Hill is distinguished by its large negative Eu anomaly and 
Table 2. Analytical data for plutons in the Saint John Area.

\begin{tabular}{|c|c|c|c|c|c|c|}
\hline \multirow[b]{2}{*}{ Sample } & \multicolumn{3}{|c|}{ Brookville Gneiss } & \multicolumn{3}{|c|}{ Fairville } \\
\hline & GSC1 & GSC29 & GSC61 & NB84 & NB88 & NB89 \\
\hline \multicolumn{7}{|l|}{ wt. \% } \\
\hline $\mathrm{SiO}_{2}$ & 72.14 & 69.89 & 66.90 & 71.49 & 64.75 & 60.85 \\
\hline $\mathrm{TiO}_{2}$ & 0.27 & 0.43 & 0.55 & 0.44 & 0.67 & 0.99 \\
\hline $\mathrm{Al}_{2} \mathrm{O}_{3}$ & 14.20 & 14.29 & 15.90 & 13.03 & 14.45 & 14.40 \\
\hline $\mathrm{Fe}_{2} \mathrm{O}_{3}$ & 0.62 & 2.20 & 1.72 & 0.71 & 1.09 & 1.40 \\
\hline $\mathrm{FeO}$ & 1.63 & 1.83 & 2.40 & 2.10 & 3.97 & 7.15 \\
\hline $\mathrm{MnO}$ & 0.05 & 0.06 & 0.07 & 0.04 & 0.08 & 0.16 \\
\hline $\mathrm{MgO}$ & 0.96 & 1.31 & 1.86 & 0.64 & 1.02 & 1.52 \\
\hline $\mathrm{CaO}$ & 2.49 & 1.61 & 3.72 & 1.91 & 3.30 & 3.30 \\
\hline $\mathrm{Na}_{2} \mathrm{O}$ & 3.41 & 2.73 & 3.23 & 3.30 & 3.60 & 2.91 \\
\hline $\mathrm{K}_{2} \mathrm{O}$ & 3.29 & 3.44 & 1.59 & 4.41 & 3.35 & 2.79 \\
\hline Total & 99.06 & 97.97 & 97.94 & 98.07 & 96.28 & 95.47 \\
\hline \multicolumn{7}{|l|}{ ppm } \\
\hline $\mathrm{Sc}$ & 7.1 & 9.6 & 9.4 & 8.6 & 13.6 & 21.4 \\
\hline V & 49 & 63 & 76 & 28.2 & 46 & 66 \\
\hline $\mathrm{Cr}$ & 14.7 & 29.9 & 32 & 19.3 & 22.1 & 24.9 \\
\hline Co & 3.9 & 9.0 & 10.3 & 3.9 & 6.6 & 9.6 \\
\hline $\mathrm{Ni}$ & 6.2 & 14.2 & 22 & 4.8 & 5.8 & 7.7 \\
\hline $\mathrm{Cu}$ & 7.4 & 22.8 & 6.4 & 46.8 & 22.6 & 23.7 \\
\hline $\mathrm{Zn}$ & 27 & 52 & 46 & 25.6 & 46 & 149 \\
\hline $\mathrm{Rb}$ & 83 & 145 & 67 & 103 & 87 & 97 \\
\hline Cs & 2.1 & 4.5 & 1.3 & 1.4 & 2.9 & 1.3 \\
\hline $\mathrm{Sr}$ & 124 & 110 & 224 & 154 & 183 & 19 \\
\hline $\mathrm{Ba}$ & 458 & 502 & 466 & 848 & 705 & 809 \\
\hline $\mathrm{La}$ & 32.0 & 37.0 & 21.4 & 39.5 & 42.0 & 43.6 \\
\hline $\mathrm{Ce}$ & 58.5 & 78.3 & 42.1 & 79.3 & 84.8 & 88.4 \\
\hline Nd & 27.2 & 35.2 & 18.3 & 29.3 & 39.8 & 50.0 \\
\hline Sm & 3.95 & 6.81 & 3.20 & 6.68 & 10.00 & 12.08 \\
\hline $\mathrm{Eu}$ & 0.87 & 1.14 & 0.94 & 1.61 & 2.27 & 2.71 \\
\hline Gd & 5.1 & 6.8 & 4.0 & 6.5 & 9.0 & 12.6 \\
\hline $\mathrm{Tb}$ & 0.85 & 1.13 & 0.60 & 1.08 & 1.45 & 1.86 \\
\hline $\mathrm{Tm}$ & 0.49 & 0.56 & 0.29 & 0.63 & 0.78 & 0.87 \\
\hline $\mathrm{Yb}$ & 3.51 & 3.85 & 2.01 & 4.32 & 5.60 & 6.20 \\
\hline $\mathrm{Lu}$ & 0.53 & 0.55 & 0.30 & 0.66 & 0.85 & 0.92 \\
\hline$Y$ & 31.0 & 38.2 & 19.0 & 41.2 & 56 & 66 \\
\hline $\mathrm{Nb}$ & 10.1 & 13.5 & 11.9 & 15.8 & 19.8 & 24.5 \\
\hline $\mathrm{Pb}$ & 12.6 & 7.0 & 4.5 & 12.1 & 11.9 & 17.6 \\
\hline $\mathrm{Zr}_{\mathbf{r}}$ & 100 & 176 & 191 & 292 & 334 & 466 \\
\hline $\mathrm{Hf}$ & 3.68 & 5.77 & 5.90 & 9.2 & 9.5 & 11.9 \\
\hline $\mathrm{Ta}$ & 0.81 & 1.06 & 0.77 & 1.24 & 1.23 & 1.44 \\
\hline Th & 16.1 & 16.8 & 6.7 & 11.4 & 7.8 & 5.47 \\
\hline $\mathrm{U}$ & 3.82 & 2.32 & 1.18 & 2.83 & 2.39 & 1.18 \\
\hline Ga & 13.5 & 16.8 & 15.3 & 12.8 & 17.8 & 20.5 \\
\hline
\end{tabular}


Table 2. Continued.

\begin{tabular}{|c|c|c|c|c|c|c|c|c|c|}
\hline \multirow[b]{2}{*}{ Sample } & \multicolumn{2}{|c|}{ Rockwood Park } & \multicolumn{3}{|c|}{ Renforth } & \multicolumn{4}{|c|}{ Mayflower Lake } \\
\hline & NB85 & NB86 & NB76 & NB78 & NB79 & NB80 & NB81 & NB82 & NB83 \\
\hline \multicolumn{10}{|l|}{ wt. \% } \\
\hline $\mathrm{SiO}_{2}$ & 62.80 & 62.20 & 57.29 & 61.10 & 65.77 & 54.90 & 57.71 & 56.61 & 61.72 \\
\hline $\mathrm{TiO}_{2}$ & 0.48 & 0.36 & 0.51 & 0.34 & 0.26 & 0.45 & 0.55 & 0.53 & 0.43 \\
\hline $\mathrm{Al}_{2} \mathrm{O}_{3}$ & 17.44 & 17.68 & 17.91 & 17.68 & 15.64 & 16.86 & 16.37 & 17.08 & 16.45 \\
\hline $\mathrm{Fe}_{2} \mathrm{O}_{3}$ & 2.11 & 1.26 & 2.83 & 2.21 & 1.16 & 1.40 & 2.23 & 1.90 & 1.41 \\
\hline $\mathrm{FeO}$ & 3.86 & 3.47 & 4.96 & 3.64 & 3.43 & 7.05 & 5.63 & 5.17 & 5.16 \\
\hline $\mathrm{MnO}$ & 0.08 & 0.09 & 0.15 & 0.12 & 0.08 & 0.16 & 0.13 & 0.13 & 0.12 \\
\hline $\mathrm{MgO}$ & 1.94 & 1.75 & 3.50 & 2.90 & 1.57 & 4.94 & 4.13 & 4.65 & 3.00 \\
\hline $\mathrm{CaO}$ & 3.31 & 4.03 & 5.61 & 5.28 & 4.22 & 7.43 & 6.10 & 7.14 & 5.71 \\
\hline $\mathrm{Na}_{2} \mathrm{O}$ & 4.03 & 4.36 & 3.30 & 3.13 & 3.16 & 2.63 & 2.91 & 2.88 & 2.87 \\
\hline $\mathrm{K}_{2} \mathrm{O}$ & 1.98 & 1.81 & 1.17 & 1.82 & 2.44 & 1.32 & 1.21 & 1.20 & 1.89 \\
\hline $\begin{array}{l}\text { Total } \\
\text { ppm }\end{array}$ & 98.03 & 97.01 & 97.23 & 98.22 & 97.73 & 97.14 & 96.97 & 97.29 & 98.76 \\
\hline Sc & 11.0 & 7.8 & 18.9 & 12.3 & 9.3 & 25.3 & 21.2 & 21.8 & 19.9 \\
\hline V & 77 & 64 & 139 & 90 & 64 & 161 & 128 & 140 & 126 \\
\hline $\mathrm{Cr}$ & 20.9 & 22.9 & 23.7 & 23.8 & 19.9 & 97 & 83 & 118 & 45 \\
\hline Co & 10.5 & 9.81 & 18.6 & 14.9 & 10.8 & 24.4 & 21.2 & 20.9 & 19.1 \\
\hline $\mathrm{Ni}$ & 3.6 & 5.1 & 9.0 & 10.4 & 6.2 & 39.1 & 33.5 & 39.1 & 20.1 \\
\hline $\mathrm{Cu}$ & 33.6 & 41 & 74 & 24.1 & 28.1 & 79 & 64 & 53 & 91 \\
\hline $\mathrm{Zn}$ & 51 & 46 & 75 & 59 & 51 & 77 & 70 & 64 & 73 \\
\hline $\mathrm{Rb}$ & 75 & 53 & 48 & 55 & 80 & 48 & 42.4 & 39.5 & 57 \\
\hline Cs & 2.7 & 1.0 & 1.8 & 3.5 & 4.7 & 1.7 & 2.1 & 2.9 & 1.6 \\
\hline $\mathrm{Sr}$ & 206 & 266 & 362 & 332 & 218 & 333 & 370 & 401 & 348 \\
\hline $\mathrm{Ba}$ & 305 & 377 & 378 & 300 & 316 & 234 & 285 & 292 & 359 \\
\hline $\mathrm{La}$ & 20.4 & 13.0 & 14.6 & 16.2 & 12.4 & 14.5 & 19.0 & 16.0 & 23.2 \\
\hline $\mathrm{Ce}$ & 44.9 & 22.8 & 30.0 & 30.1 & 24.4 & 35.5 & 42.8 & 37.3 & 57 \\
\hline Nd & 18.7 & 9.2 & 14.3 & 12.4 & 10.5 & 17.5 & 18.9 & 17.8 & 27.9 \\
\hline $\mathrm{Sm}$ & 4.32 & 2.06 & 3.38 & 2.83 & 2.22 & 3.71 & 3.74 & 3.76 & 5.53 \\
\hline Eu & 1.13 & 0.71 & 1.06 & 0.68 & 0.64 & 0.99 & 1.10 & 1.01 & 1.30 \\
\hline Gd & 5.1 & 2.0 & 3.7 & 2.7 & n.d. & 3.4 & 3.8 & 3.6 & 5.1 \\
\hline $\mathrm{Tb}$ & 0.89 & 0.30 & 0.61 & 0.42 & 0.32 & 0.52 & 0.57 & 0.57 & 0.77 \\
\hline $\mathrm{Tm}$ & 0.60 & 0.16 & 0.32 & 0.20 & 0.19 & 0.27 & 0.26 & 0.27 & 0.35 \\
\hline Yb & 4.50 & 1.13 & 2.29 & 1.30 & 1.32 & 1.89 & 1.78 & 1.89 & 2.46 \\
\hline Lu & 0.69 & 0.16 & 0.35 & 0.18 & 0.19 & 0.28 & 0.27 & 0.27 & 0.36 \\
\hline $\mathbf{Y}$ & 38.3 & 11.7 & 24.2 & 13.9 & 12.1 & 19.9 & 17.5 & 19.0 & 26.1 \\
\hline $\mathrm{Nb}$ & 10.9 & 4.5 & 6.3 & 6.5 & 7.7 & 7.5 & 7.5 & 6.7 & 9.3 \\
\hline $\mathrm{Pb}$ & 12.8 & 5.3 & 12.3 & 10.7 & 17.8 & 8.1 & 8.4 & 5.1 & 15.7 \\
\hline $\mathrm{Zr}$ & 137 & 108 & 123 & 71 & 89 & 82 & 84 & 88 & 120 \\
\hline $\mathrm{Hf}$ & 4.19 & 2.80 & 3.84 & 1.98 & 2.99 & 2.30 & 2.66 & 2.35 & 3.91 \\
\hline $\mathrm{Ta}$ & 0.95 & 0.21 & 0.26 & 0.54 & 0.63 & 0.42 & 0.58 & 0.39 & 0.70 \\
\hline Th & 8.64 & 2.21 & 2.16 & 4.96 & 6.83 & 3.62 & 4.73 & 3.98 & 6.11 \\
\hline $\mathrm{U}$ & 1.39 & 0.27 & 0.79 & 0.92 & 1.41 & 1.19 & 1.74 & 0.87 & 1.7 \\
\hline $\mathrm{Ga}$ & 17.6 & 15.4 & 17.7 & 17.0 & 15.7 & 17.9 & 18.1 & 17.9 & 18.0 \\
\hline
\end{tabular}


Table 2. Continued.

\begin{tabular}{|c|c|c|c|c|c|c|c|c|c|}
\hline \multirow[b]{2}{*}{ Sample } & \multicolumn{3}{|c|}{ Milkish Head } & \multicolumn{5}{|c|}{ Ludgate Lake } & \multirow{2}{*}{$\begin{array}{r}\begin{array}{r}\text { Perch } \\
\text { Lake }\end{array} \\
\text { NB97 }\end{array}$} \\
\hline & NB73 & NB74 & NB75 & NB90 & NB92 & NB93 & NB94 & NB106 & \\
\hline \multicolumn{10}{|l|}{ wt. \% } \\
\hline $\mathrm{SiO}_{2}$ & 66.73 & 68.08 & 67.37 & 67.21 & 70.61 & 65.40 & 64.44 & 65.27 & 58.99 \\
\hline $\mathrm{TiO}_{2}$ & 0.42 & 0.26 & 0.39 & 0.35 & 0.26 & 0.38 & 0.37 & 0.39 & 0.54 \\
\hline $\mathrm{Al}_{2} \mathrm{O}_{3}$ & 14.61 & 14.06 & 13.97 & 15.01 & 14.56 & 15.27 & 16.14 & 15.93 & 16.68 \\
\hline $\mathrm{Fe}_{2} \mathrm{O}_{3}$ & 0.81 & 0.63 & 0.91 & 0.93 & 0.63 & 1.48 & 1.11 & 1.19 & 1.10 \\
\hline $\mathrm{FeO}$ & 3.76 & 2.45 & 3.19 & 3.83 & 2.22 & 3.48 & 3.73 & 4.16 & 4.89 \\
\hline $\mathrm{MnO}$ & 0.10 & 0.08 & 0.07 & 0.09 & 0.06 & 0.08 & 0.10 & 0.11 & 0.12 \\
\hline $\mathrm{MgO}$ & 2.28 & 1.15 & 1.16 & 2.00 & 0.91 & 2.28 & 1.74 & 2.18 & 2.85 \\
\hline $\mathrm{CaO}$ & 3.12 & 2.11 & 2.15 & 3.10 & 2.64 & 3.30 & 3.31 & 3.44 & 3.37 \\
\hline $\mathrm{Na}_{2} \mathrm{O}$ & 2.96 & 3.65 & 3.17 & 3.64 & 3.66 & 3.41 & 3.58 & 3.98 & 3.80 \\
\hline $\mathrm{K}_{2} \mathrm{O}$ & 3.42 & 3.24 & 4.04 & 2.41 & 2.63 & 2.07 & 2.35 & 1.57 & 2.93 \\
\hline Total & 98.21 & 95.71 & 96.42 & 98.57 & 98.18 & 97.15 & 96.87 & 98.22 & 95.27 \\
\hline \multicolumn{10}{|l|}{ ppm } \\
\hline $\mathrm{Sc}$ & 12.6 & 5.8 & 9.8 & 9.1 & 4.5 & 8.8 & 8.3 & 10.6 & 16.7 \\
\hline V & 71 & 43 & 55 & 55 & 36 & 64 & 56 & 69 & 102 \\
\hline $\mathrm{Cr}_{\mathrm{r}}$ & 67 & 17.6 & 30.8 & 28 & 20 & 23.4 & 24.4 & 29.1 & 51 \\
\hline Co & 11.2 & 7.3 & 6.9 & 10.6 & 4.7 & 8.2 & 8.2 & 10.7 & 17.2 \\
\hline $\mathrm{Ni}$ & 20.2 & 3.4 & 7.5 & 6.6 & 3.1 & 6.7 & 5.1 & 7.2 & 20.6 \\
\hline $\mathrm{Cu}$ & 24.7 & 137 & 60 & 21.4 & 125 & 21.7 & 25.5 & 27.1 & 29.9 \\
\hline $\mathrm{Zn}$ & 67 & 37.6 & 47 & 43 & 32.7 & 46.8 & 51.4 & 50 & 83 \\
\hline $\mathrm{Rb}$ & 103 & 92 & 121 & 62 & 62 & 46.9 & 53 & 42 & 87 \\
\hline Cs & 1.56 & 4.3 & 1.81 & 1.2 & 1.4 & 1.8 & 1.4 & 1.6 & 2.2 \\
\hline $\mathrm{Sr}$ & 151 & 107 & 160 & 204 & 204 & 216 & 214 & 210 & 226 \\
\hline $\mathrm{Ba}$ & 435 & 496 & 619 & 382 & 462 & 329 & 404 & 272 & 445 \\
\hline La & 28.2 & 20.3 & 24.7 & 14.6 & 20.8 & 15.2 & 19.4 & 16.3 & 21.5 \\
\hline $\mathrm{Ce}$ & 45.2 & 38.9 & 45.6 & 26.0 & 35.3 & 29.2 & 37.4 & 35.9 & 55.3 \\
\hline Nd & 24.8 & 15.3 & 19.0 & 13.0 & 11.8 & 10.6 & 14.7 & 15.7 & 24.8 \\
\hline $\mathrm{Sm}$ & 5.41 & 2.72 & 3.30 & 2.74 & 2.17 & 2.53 & 3.31 & 3.36 & 5.48 \\
\hline $\mathrm{Eu}$ & 0.89 & 0.67 & 1.04 & 0.71 & 0.63 & 0.80 & 0.86 & 0.82 & 1.10 \\
\hline $\mathrm{Gd}$ & 5.2 & 2.5 & n.d. & 2.7 & n.d. & 2.6 & 3.0 & 3.3 & 5.2 \\
\hline $\mathrm{Tb}$ & 0.81 & 0.38 & 0.53 & 0.45 & 0.31 & 0.44 & 0.45 & 0.50 & 0.83 \\
\hline $\mathrm{Tm}$ & 0.39 & 0.23 & 0.29 & 0.24 & 0.19 & 0.28 & 0.26 & 0.29 & 0.42 \\
\hline Yb & 2.52 & 1.60 & 2.07 & 1.63 & 1.40 & 2.00 & 1.83 & 2.08 & 2.87 \\
\hline Lu & 0.37 & 0.22 & 0.31 & 0.25 & 0.20 & 0.30 & 0.27 & 0.31 & 0.43 \\
\hline $\mathbf{Y}$ & 29.4 & 14.9 & 20.6 & 14.6 & 13.0 & 15.6 & 18.7 & 18.2 & 32.6 \\
\hline $\mathrm{Nb}$ & 11.1 & 6.7 & 10.5 & 6.6 & 7.1 & 6.3 & 7.0 & 7.2 & 8.5 \\
\hline $\mathrm{Pb}$ & 30.2 & 10.3 & 17.9 & 5.5 & 10.1 & 6.3 & 8.1 & 8.1 & 9.1 \\
\hline $\mathrm{Zr}$ & 139 & 122 & 180 & 102 & 98 & 108 & 115 & 105 & 203 \\
\hline Hf & 4.25 & 3.44 & 5.47 & 3.31 & 2.86 & 3.54 & 3.30 & 3.55 & 5.47 \\
\hline Ta & 1.00 & 0.51 & 0.92 & 0.48 & 0.63 & 0.48 & 0.51 & 0.49 & 0.50 \\
\hline Th & 9.26 & 7.62 & 14.6 & 6.19 & 5.59 & 4.81 & 5.46 & 5.36 & 6.87 \\
\hline U & 2.33 & 1.81 & 3.52 & 1.07 & 1.56 & 1.26 & 0.92 & 1.24 & 1.48 \\
\hline $\mathrm{Ga}$ & 14.2 & 13.5 & 14.2 & 14.6 & 12.7 & 16.5 & 15.1 & 15.9 & 16.4 \\
\hline
\end{tabular}


Table 2. Continued.

\begin{tabular}{|c|c|c|c|c|c|c|c|c|}
\hline \multirow[b]{2}{*}{ Sample } & \multicolumn{4}{|c|}{ Shadow Lake } & \multicolumn{2}{|c|}{ Hanson Stream } & \multicolumn{2}{|c|}{ Prince of Wales } \\
\hline & NB98 & NB99 & NB100 & NB101 & NB104 & NB105 & NB95 & NB96 \\
\hline \multicolumn{9}{|l|}{ wt. \% } \\
\hline $\mathrm{SiO}_{2}$ & 73.39 & 60.53 & 71.14 & 53.22 & 60.70 & 68.26 & 70.15 & 71.06 \\
\hline $\mathrm{TiO}_{2}$ & 0.20 & 0.43 & 0.27 & 0.57 & 0.53 & 0.33 & 0.54 & 0.38 \\
\hline $\mathrm{Al}_{2} \mathrm{O}_{3}$ & 13.79 & 16.27 & 14.63 & 16.98 & 16.64 & 15.21 & 13.39 & 13.19 \\
\hline $\mathrm{Fe}_{2} \mathrm{O}_{3}$ & 0.48 & 2.21 & 0.70 & 1.54 & 1.97 & 1.16 & 0.64 & 0.79 \\
\hline $\mathrm{FeO}$ & 1.74 & 4.78 & 2.39 & 6.51 & 4.80 & 2.92 & 3.27 & 2.37 \\
\hline $\mathrm{MnO}$ & 0.04 & 0.17 & 0.08 & 0.14 & 0.12 & 0.08 & 0.08 & 0.05 \\
\hline $\mathrm{MgO}$ & 0.77 & 3.10 & 0.95 & 5.32 & 3.06 & 1.58 & 0.86 & 0.81 \\
\hline $\mathrm{CaO}$ & 2.73 & 5.18 & 2.86 & 8.39 & 5.70 & 3.51 & 2.29 & 1.44 \\
\hline $\mathrm{Na}_{2} \mathrm{O}$ & 3.38 & 3.50 & 4.39 & 2.97 & 3.31 & 3.49 & 3.13 & 3.14 \\
\hline $\mathrm{K}_{2} \mathrm{O}$ & 2.05 & 2.06 & 1.15 & 0.97 & 2.04 & 2.57 & 4.11 & 4.23 \\
\hline $\begin{array}{l}\text { Total } \\
\text { ppm }\end{array}$ & 98.57 & 98.23 & 98.56 & 96.61 & 98.87 & 99.11 & 98.46 & 97.46 \\
\hline Sc & 1.8 & 16.6 & 5.4 & 27.2 & 16.2 & 7.7 & 9.9 & 8.3 \\
\hline V & 35 & 130 & 30.9 & 147 & 114 & 61 & 41 & 38 \\
\hline $\mathrm{Cr}$ & 15.0 & 28.9 & 17.3 & 93 & 39 & 19.3 & 27.1 & 23 \\
\hline Co & 4.3 & 16.5 & 4.9 & 25.7 & 16.8 & 8.2 & 5.1 & 4.2 \\
\hline $\mathrm{Ni}$ & 2.0 & 9.6 & 3.6 & 23.2 & 11.2 & 5.4 & 7.5 & 6.1 \\
\hline $\mathrm{Cu}$ & 19.0 & 40.7 & 18.2 & 73 & 45.5 & 23.4 & 32.7 & 22.6 \\
\hline $\mathrm{Zn}$ & 27.1 & 64 & 32.2 & 65 & 52 & 40 & 47 & 50 \\
\hline $\mathrm{Rb}$ & 51 & 60 & 49 & 27.5 & 52 & 69 & 129 & 128 \\
\hline Cs & 1.4 & 1.3 & 1.3 & 0.7 & 1.6 & 1.4 & 1.8 & 2.9 \\
\hline $\mathrm{Sr}$ & 244 & 308 & 171 & 292 & 280 & 207 & 120 & 91 \\
\hline $\mathrm{Ba}$ & 303 & 280 & 99 & 157 & 243 & 271 & 663 & 575 \\
\hline $\mathrm{La}$ & 31.6 & 14.7 & 27.7 & 9.9 & 17.0 & 17.0 & 33.9 & 33.6 \\
\hline $\mathrm{Ce}$ & 51.3 & 32.9 & 49.7 & 25.0 & 39.7 & 33.6 & 68.4 & 65.5 \\
\hline Nd & 15.8 & 18.0 & 17.4 & 12.6 & 19.5 & 12.8 & 31.3 & 28.2 \\
\hline Sm & 1.97 & 4.30 & 3.43 & 2.93 & 4.61 & 2.69 & 7.23 & 6.32 \\
\hline Eu & 0.62 & 1.01 & 0.61 & 0.92 & 1.05 & 0.65 & 1.24 & 0.99 \\
\hline Gd & n.d. & 3.9 & n.d. & 3.6 & 3.6 & n.d. & 7.4 & 6.4 \\
\hline $\mathrm{Tb}$ & 0.24 & 0.59 & 0.51 & 0.56 & 0.56 & 0.41 & 1.11 & 0.98 \\
\hline $\mathrm{Tm}$ & 0.12 & 0.29 & 0.26 & 0.27 & 0.31 & 0.25 & 0.64 & 0.50 \\
\hline $\mathrm{Yb}$ & 0.80 & 1.94 & 1.73 & 1.80 & 2.28 & 1.73 & 4.60 & 3.55 \\
\hline $\mathbf{L u}$ & 0.12 & 0.29 & 0.23 & 0.26 & 0.34 & 0.25 & 0.68 & 0.53 \\
\hline $\mathbf{Y}$ & 6.2 & 20.5 & 18.4 & 18.2 & 20.0 & 15.3 & 40.8 & 34.9 \\
\hline $\mathrm{Nb}$ & 4.4 & 6.6 & 12.1 & 5.0 & 5.7 & 7.6 & 15.1 & 14.7 \\
\hline $\mathrm{Pb}$ & 9.0 & 21.7 & 9.5 & 6.6 & 8.8 & 9.6 & 17.2 & 20.3 \\
\hline $\mathrm{Zr}$ & 116 & 83 & 134 & 80 & 95 & 91 & 246 & 215 \\
\hline Hf & 3.56 & 2.46 & 3.91 & 2.27 & 3.21 & 2.77 & 7.8 & 6.29 \\
\hline $\mathrm{Ta}$ & 0.42 & 0.58 & 0.73 & 0.28 & 0.38 & 0.82 & 1.28 & 1.21 \\
\hline Th & 7.68 & 5.98 & 10.4 & 2.74 & 4.63 & 7.90 & 11.8 & 16.0 \\
\hline $\mathrm{U}$ & 1.15 & 1.57 & 1.76 & 0.62 & 1.16 & 1.55 & 2.20 & 3.75 \\
\hline $\mathrm{Ga}$ & 12.7 & 16.9 & 15.6 & 17.4 & 16.0 & 14.4 & 15.4 & 14.6 \\
\hline
\end{tabular}


Table 2. Continued.

\begin{tabular}{|c|c|c|c|c|c|c|}
\hline \multirow[b]{2}{*}{ Sample } & \multicolumn{2}{|c|}{ Harvey Hill } & \multicolumn{4}{|c|}{ Lingley } \\
\hline & NB102 & NB103 & NB39 & NB40 & NB41 & NB42 \\
\hline \multicolumn{7}{|l|}{ wt. \% } \\
\hline $\mathrm{SiO}_{2}$ & 77.81 & 73.55 & 71.6 & 75.38 & 76.12 & 74.65 \\
\hline $\mathrm{TiO}_{2}$ & 0.07 & 0.33 & 0.32 & 0.13 & 0.11 & 0.14 \\
\hline $\mathrm{Al}_{2} \mathrm{O}_{3}$ & 12.29 & 13.04 & 12.43 & 13.57 & 12.83 & 11.84 \\
\hline $\mathrm{Fe}_{2} \mathrm{O}_{3}$ & 0.30 & 0.46 & 1.63 & 0.61 & 0.86 & 0.54 \\
\hline $\mathrm{FeO}$ & 1.32 & 2.15 & 0.83 & 0.94 & 0.40 & 1.19 \\
\hline $\mathrm{MnO}$ & 0.01 & 0.04 & 0.04 & 0.04 & 0.05 & 0.05 \\
\hline $\mathrm{MgO}$ & 0.03 & 0.32 & 0.15 & 0.29 & 0.22 & 0.16 \\
\hline $\mathrm{CaO}$ & 0.19 & 1.14 & 1.29 & 0.69 & 0.17 & 0.93 \\
\hline $\mathrm{Na}_{2} \mathrm{O}$ & 3.86 & 3.12 & 3.52 & 3.09 & 3.18 & 3.31 \\
\hline $\mathrm{K}_{2} \mathrm{O}$ & 4.20 & 5.33 & 3.84 & 3.81 & 3.18 & 4.46 \\
\hline Total & 100.08 & 99.48 & 95.65 & 98.55 & 97.12 & 97.27 \\
\hline $\begin{array}{l}\text { ppm } \\
\text { Sc }\end{array}$ & 0.88 & 4.9 & 7.2 & 3.7 & 3.6 & 6.3 \\
\hline V & 6.2 & 21.3 & 21.1 & 9.6 & 9.7 & 13.0 \\
\hline $\mathrm{Cr}$ & 15.6 & 19.3 & 51 & 24.0 & 27.2 & 31.7 \\
\hline Co & 0.71 & 2.7 & 4.2 & 1.5 & 1.63 & 2.05 \\
\hline $\mathrm{Ni}$ & 3.7 & 4.8 & 9.5 & 4.6 & 4.6 & 7.3 \\
\hline $\mathrm{Cu}$ & 28.2 & 22.5 & 21.4 & 13.1 & 13.6 & 19.4 \\
\hline $\mathrm{Zn}$ & 39.5 & 43.2 & 42.6 & 32.7 & 46.2 & 49.3 \\
\hline $\mathrm{Rb}$ & 166 & 192 & 118 & 139 & 102 & 133 \\
\hline Cs & 0.9 & 2.3 & 9.0 & 4.6 & 5.2 & 2.06 \\
\hline $\mathrm{Sr}$ & 9.4 & 43.7 & 72.9 & 28.4 & 133 & 47.9 \\
\hline $\mathrm{Ba}$ & 44 & 606 & 524 & 686 & 496 & 769 \\
\hline $\mathrm{La}$ & 36.6 & 47.3 & 23.0 & 48.6 & 61.4 & 44.0 \\
\hline $\mathrm{Ce}$ & 84.3 & 102.8 & 42.5 & 88.3 & 114 & 87.5 \\
\hline Nd & 37.2 & 40.5 & 19.4 & 31.4 & 41.5 & 36.4 \\
\hline $\mathrm{Sm}$ & 10.71 & 9.15 & 5.22 & 6.17 & 7.76 & 8.52 \\
\hline $\mathrm{Eu}$ & 0.13 & 1.05 & 0.95 & 0.89 & 1.35 & 1.29 \\
\hline Gd & 12.9 & 9.4 & 6.3 & 5.9 & n.d. & 9.0 \\
\hline $\mathrm{Tb}$ & 2.21 & 1.47 & 1.07 & 0.85 & 0.88 & 1.41 \\
\hline $\mathrm{Tm}$ & 1.45 & 0.99 & 0.64 & 0.44 & 0.42 & 0.76 \\
\hline $\mathrm{Yb}$ & 11.0 & 7.18 & 4.5 & 3.08 & 2.89 & 5.37 \\
\hline Lu & 1.63 & 1.10 & 0.67 & 0.46 & 0.42 & 0.80 \\
\hline $\mathrm{Y}$ & 97 & 71 & 46 & 33.3 & 28.4 & 55 \\
\hline $\mathrm{Nb}$ & 24.0 & 24.2 & 16.4 & 13.6 & 14.3 & 16.3 \\
\hline $\mathrm{Pb}$ & 17.1 & 19.6 & 18.2 & 6.6 & 19.8 & 21.1 \\
\hline $\mathrm{Zr}$ & 172 & 319 & 303 & 121 & 107 & 233 \\
\hline $\mathrm{Hf}$ & 8.6 & 9.2 & 8.45 & 3.84 & 3.73 & 7.32 \\
\hline $\mathrm{Ta}$ & 1.44 & 1.79 & 1.10 & 0.99 & 1.01 & 1.16 \\
\hline Th & 21.9 & 18.4 & 16.1 & 14.8 & 18.0 & 16.2 \\
\hline $\mathrm{U}$ & 4.18 & 2.74 & 3.52 & 2.94 & 1.52 & 3.75 \\
\hline $\mathrm{Ga}$ & 20.5 & 15.4 & 13.1 & 15.7 & 13.0 & 13.3 \\
\hline
\end{tabular}




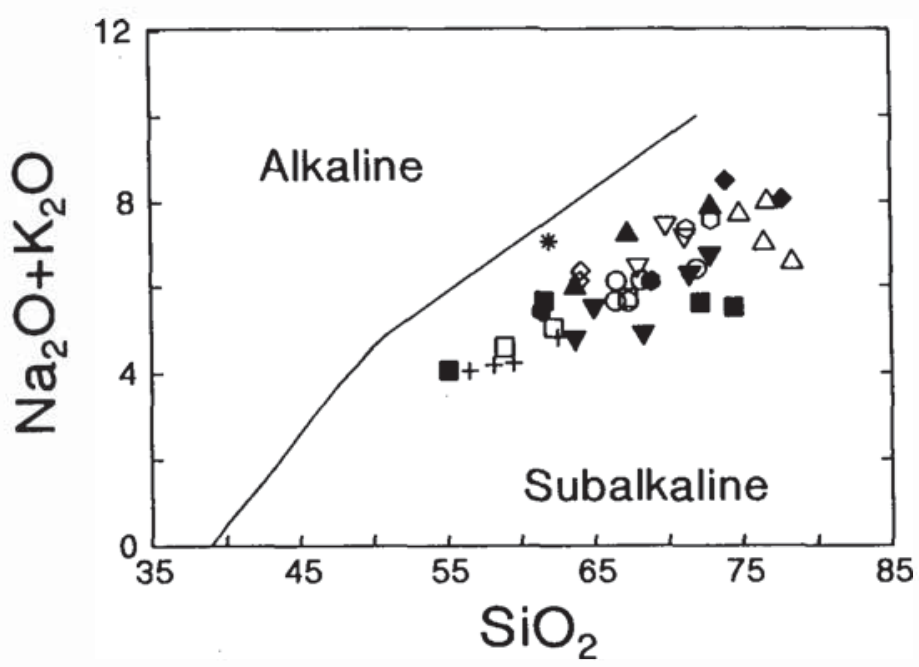

Fig. 2. Total alkalis versus $\mathrm{SiO}_{2}$ (wt. \%). Brookville terrane plutons are chemically subalkaline. Symbols: $(\Delta)$ Lingley, $(\mathbf{\Delta})$ Fairville, ( $\square$ ) Renforth, (ם) Shadow Lake, ( $(\diamond)$ Rockwood Park, $(\checkmark)$ Harvey Hill, (O) Ludgate Lake, (O) Prince of Wales, ( ) Hanson Stream, $(\nabla)$ Milkish Head, (*) Perch Lake, (+) Mayflower Lake, ( $\boldsymbol{\nabla})$ Brookville gneiss. flatter HREE pattern relative to the Lingley and Prince of Wales. The Fairville and Rockwood Park patterns are similar (Fig. 9) in terms of slope and size of the Eu anomaly. However, the previously noted chemical differences support the petrographic division. The Rockwood Park sample that has a negative $\mathrm{Eu}$ anomaly is a fine grained phase of the pluton, whereas the sample with the slight positive Eu anomaly is a coarse grained phase, and the observed pattern most likely reflects an incomplete separation of solids and liquid. Milkish Head and Renforth were once considered to be part of the same unit. However, the Renforth has a flatter REE pattern and a lower total REE content then the Milkish Head (Fig. 10). With one exception there are either no Eu anomalies or small negative Eu anomalies, suggesting minimal feldspar fractionation. The Perch Lake and Mayflower Lake quartz diorites and tonalites have relatively flat REE patterns and either no Eu anomaly or a small negative Eu anomaly (Fig. 11). The Hanson Stream and Ludgate Lake patterns are also relatively flat (Fig. 11) and are similar in shape to those of the Renforth. The Shadow Lake Pluton has two distinct phases, one a coarse grained granite and the second a more mafic, medium grained quartz diorite. The REE patterns for these two phases are different (Fig. 12). The dioritic phase

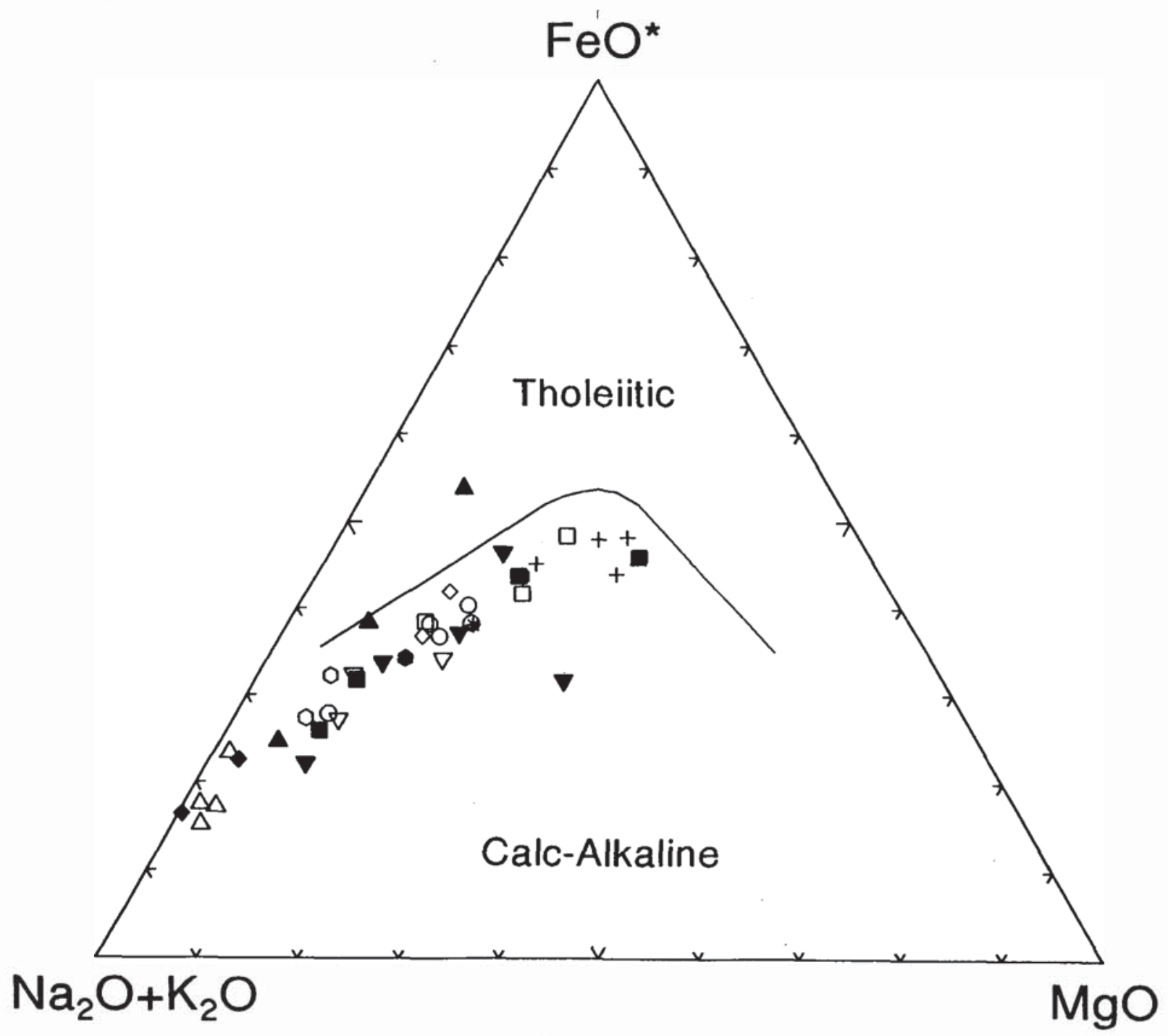

Fig. 3. Alkalis-FeO $-\mathrm{MgO}$ triangular plot. Brookville terrane plutons are chemically calc-alkaline. See Figure 2 for symbols. 


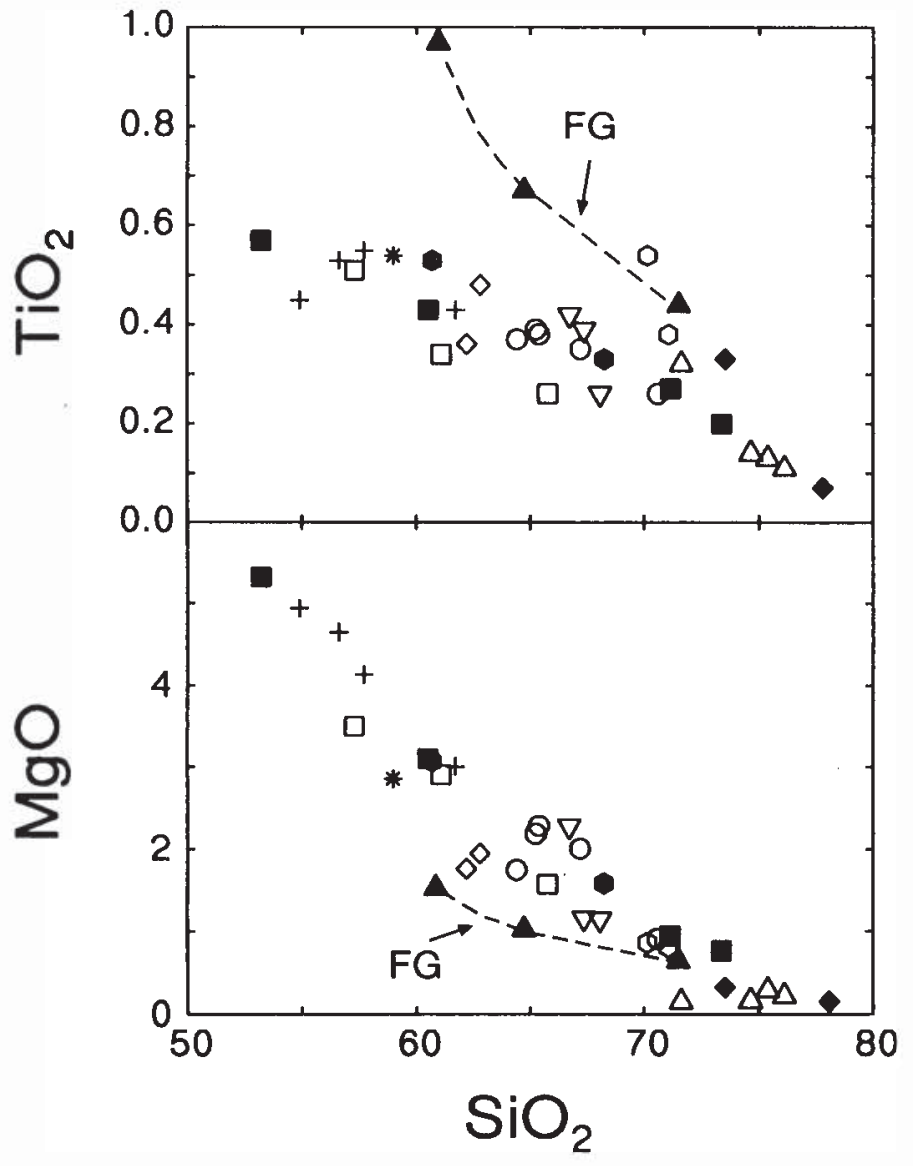

Fig. 4. $\mathrm{TiO}_{2}$ and $\mathrm{MgO}$ versus $\mathrm{SiO}_{2}$ (wt. \%). See Figure 2 for symbols. FG = Fairville granite. has a relatively flat pattern with a slight negative REE anomaly and is similar to the Mayflower Lake. The granitic phase is significantly enriched in the LREE. One sample has a distinct negative Eu anomaly, whereas the other has a slight positive Eu anomaly. The latter sample also has a much lower abundance of HREE. These two rocks are mineralogically the same and texturally similar. However, the simplest explanation for the observed REE patterns is to infer that there was incomplete separation of liquid and solid phases for the sample with the slight positive Eu anomaly. The Brookville Gneiss shows relatively steep LREE patterns (Fig. 12) and most samples have small negative Eu anomalies.

\section{Discussion}

The chemical data and petrography of the various plutons indicate that magmatic evolution was largely controlled by fractional crystallization of hornblende and plagioclase, in the mafic end members, and plagioclase and alkali feldspar, in the felsic end members. These magmas probably did not evolve as closed systems, but without isotopic data it is not possible to assess the significance of open system processes. Subsequent alteration may have caused some redistribution of the alkali and alkaline earth elements, which may be responsible for some of the "noise" in the data. However, relatively good correlation between $\mathrm{SiO}_{2}$ and $\mathrm{K}_{2} \mathrm{O}$ (Fig. 5) suggests that alkali mobility was limited.

Although all of the plutons are broadly similar in terms of major and trace element geochemistry, several groups can be distinguished. The Fairville granite is the oldest pluton

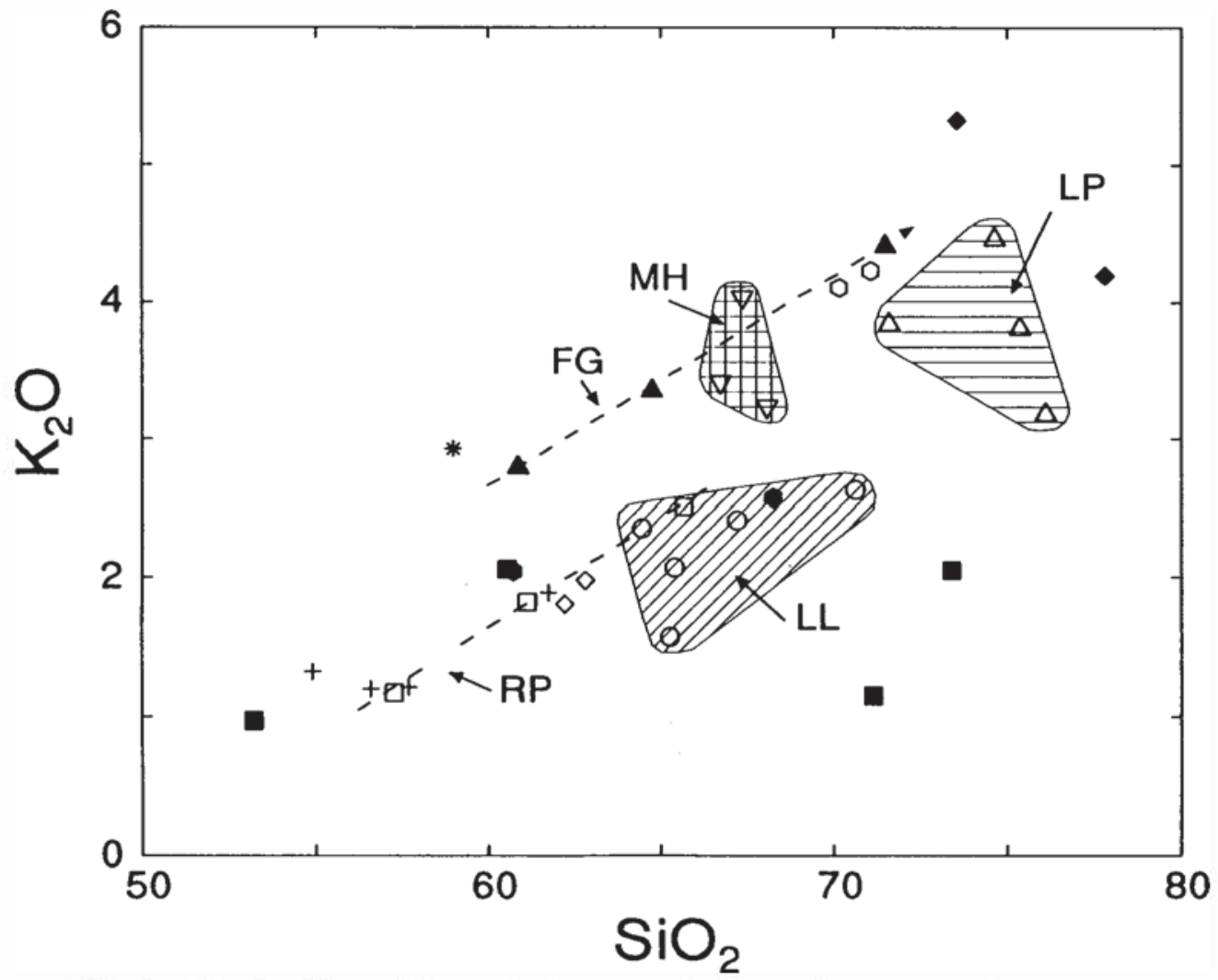

Fig. 5. $\mathrm{K}_{2} \mathrm{O}$ versus $\mathrm{SiO}_{2}$ (wt. \%). See Figure 2 for symbols. FG = Fairville granite, LL = Ludgate Lake, LP = Lingley pluton, MH = Milkish Head, RP = Renforth pluton. 


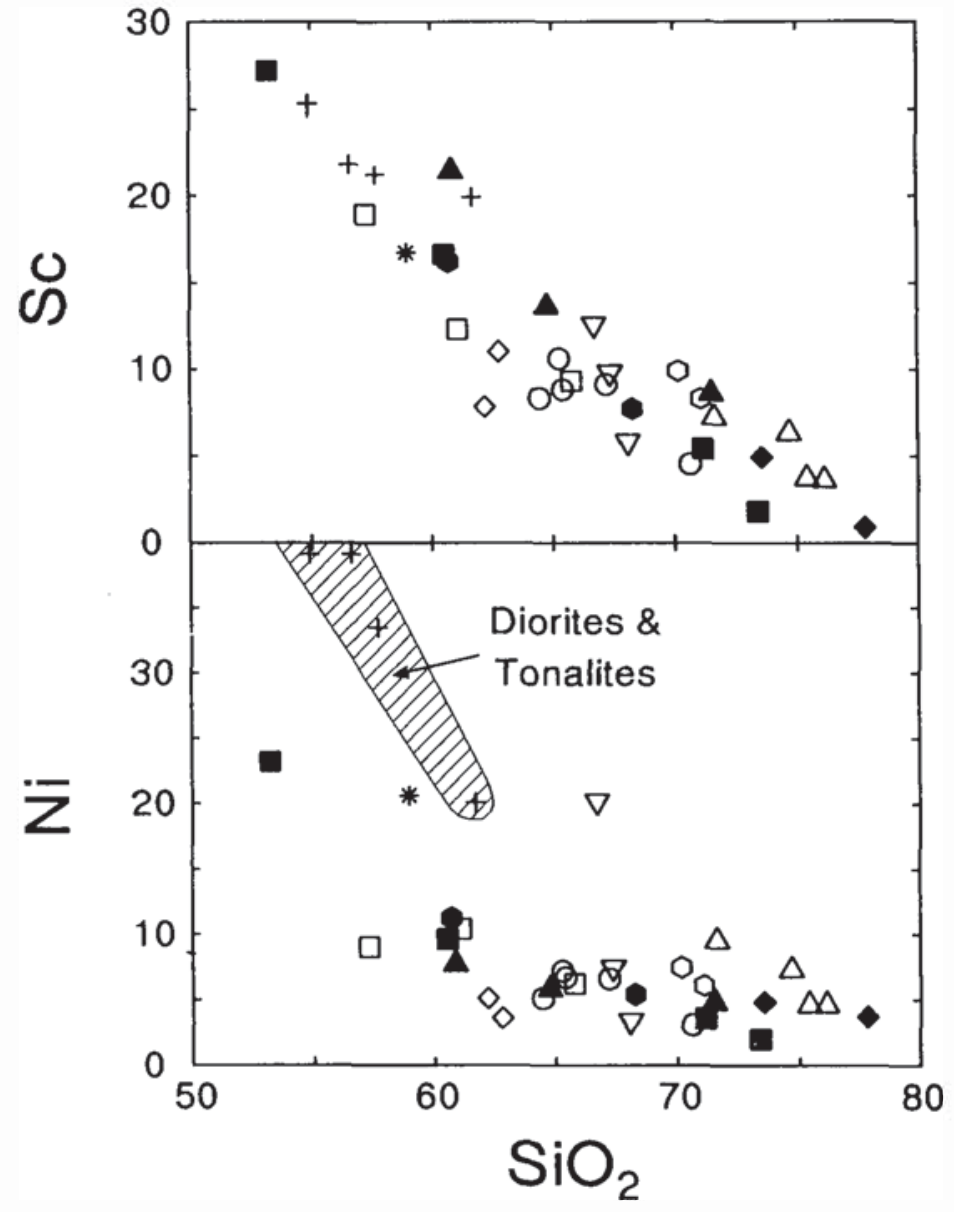

Fig. 6. Sc and $\mathrm{Ni}(\mathrm{ppm})$ versus $\mathrm{SiO}_{2}$ (wt. \%). See Figure 2 for symbols.

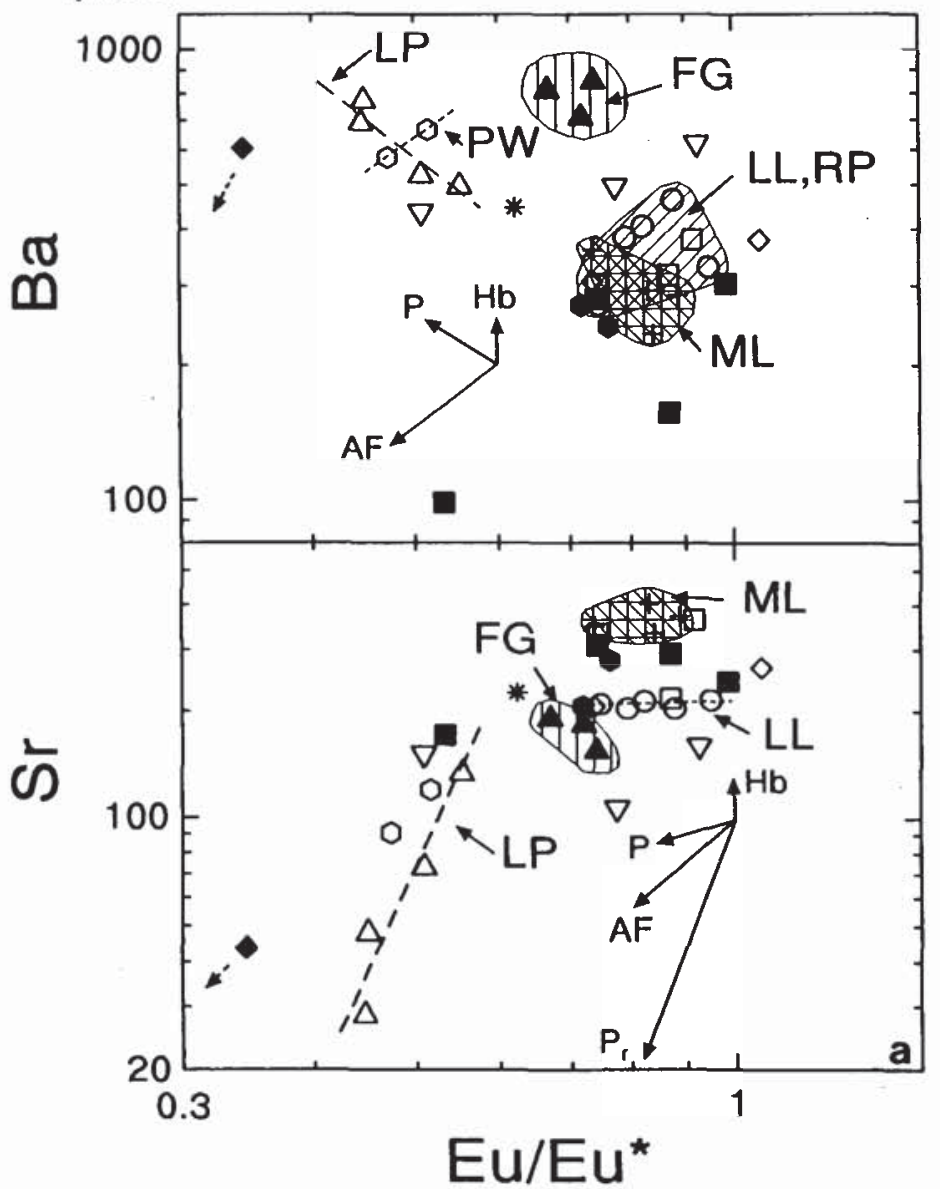

and is chemically distinguished from the other plutons by its relatively high $\mathrm{TiO}_{2}, \mathrm{~K}_{2} \mathrm{O}, \mathrm{Ba}, \mathrm{Nb}$ and $\mathrm{Zr}$ and relatively low $\mathrm{MgO}$ and Sr. Ludgate Lake, Renforth, Hanson Stream, Rockwood Park, and the mafic member of Shadow Lake form a second group characterized by similarities in $\mathrm{Sr}, \mathrm{Ba}, \mathrm{Nb}$, $\mathrm{Zr}$ and REE contents. The Mayflower Lake and Perch Lake quartz diorites and tonalites plot with the second group on many of the diagrams, but are distinguished by their relatively high Ni content. A third group consists of the Lingley, Prince of Wales, and Harvey Hill plutons, all with well-developed negative $\mathrm{Eu}$ anomalies, relatively high total REE and essentially flat HREE patterns. The Milkish Head Pluton does not consistently plot with any of these groups.

On the basis of current geochronology, the chemical groups are not correlative with geologic age. All the U/Pb zircon ages for the Brookville terrane plutons fall between 538 and $550 \mathrm{Ma}$. Ages younger than $538 \mathrm{Ma}$ are derived from the hornblende Ar/Ar system. Three plutons have been dated by both methods. For the Fairville and French Village plutons, $\mathrm{Ar} / \mathrm{Ar}$ isotope correlation ages agree within experimental error with $U / \mathrm{Pb}$ zircon ages (Table 1). For the third pluton, Rockwood Park, a range of $\mathrm{Ar} / \mathrm{Ar}$ ages have been determined but the oldest of these ages agrees with the U/ $\mathrm{Pb}$ zircon age (Table 1). Previous authors (Dallmeyer and Nance, 1992; White, 1995) have interpreted the younger $\mathrm{Ar} / \mathrm{Ar}$ ages to be cooling ages, thus implying relatively deep burial and an extended period of uplift for this terrane. An alternative interpretation is that at least some of these younger $\mathrm{Ar} / \mathrm{Ar}$ ages are intrusive ages, indicating an extended period of magmatism, and do not necessarily imply deep burial. This question can be resolved if $\mathrm{U} / \mathrm{Pb}$ zircon ages are determined for some of the plutons which give the younger Ar/

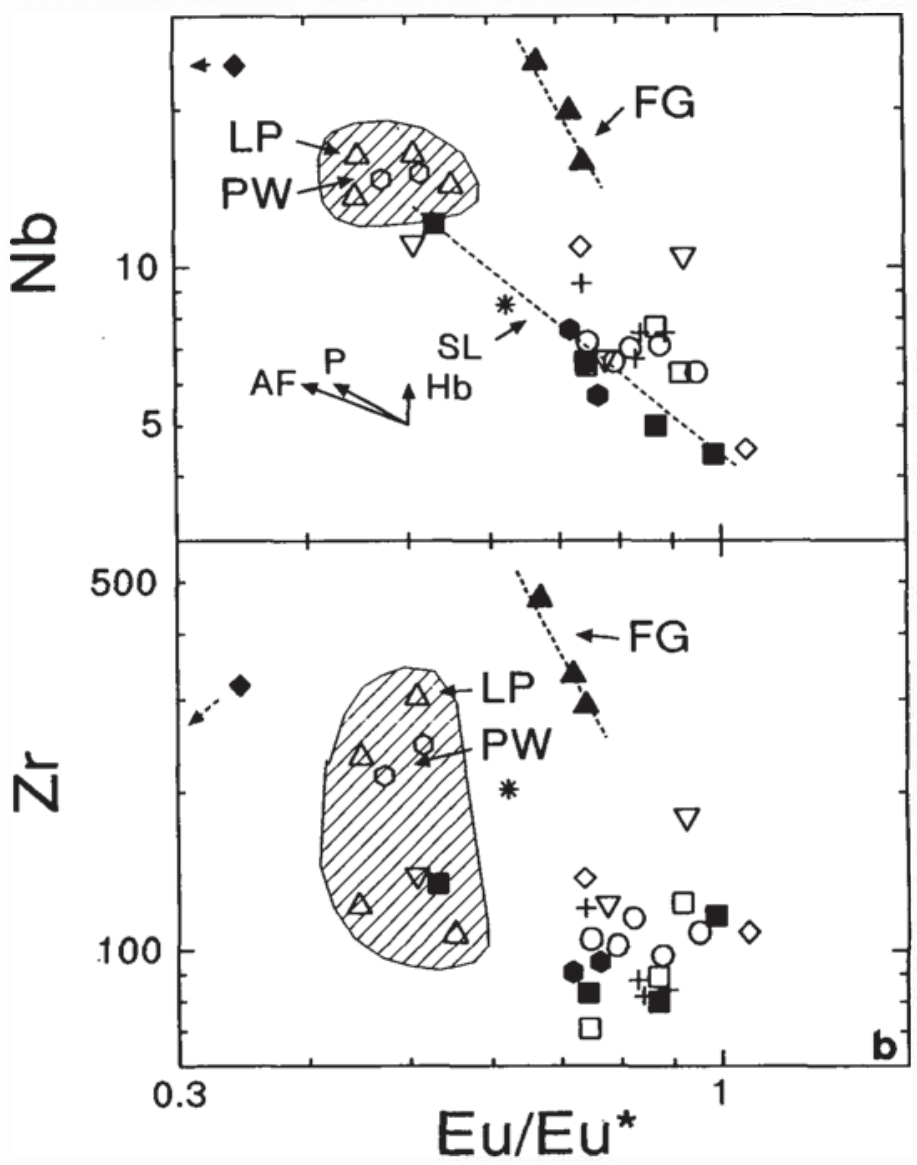




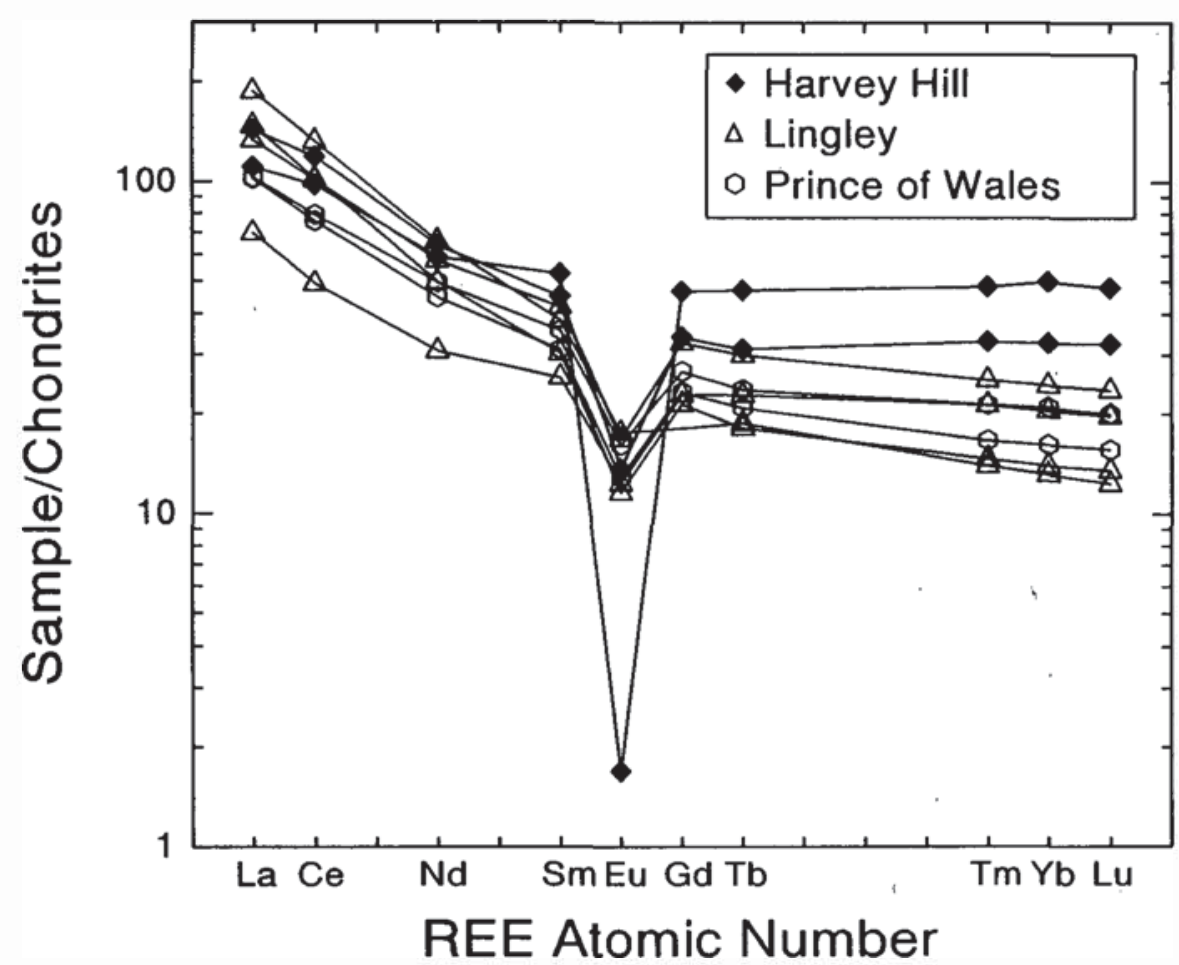

Fig. 8. Chondrite normalized REE plots. Chondrite normalization values from Nakamura (1974).

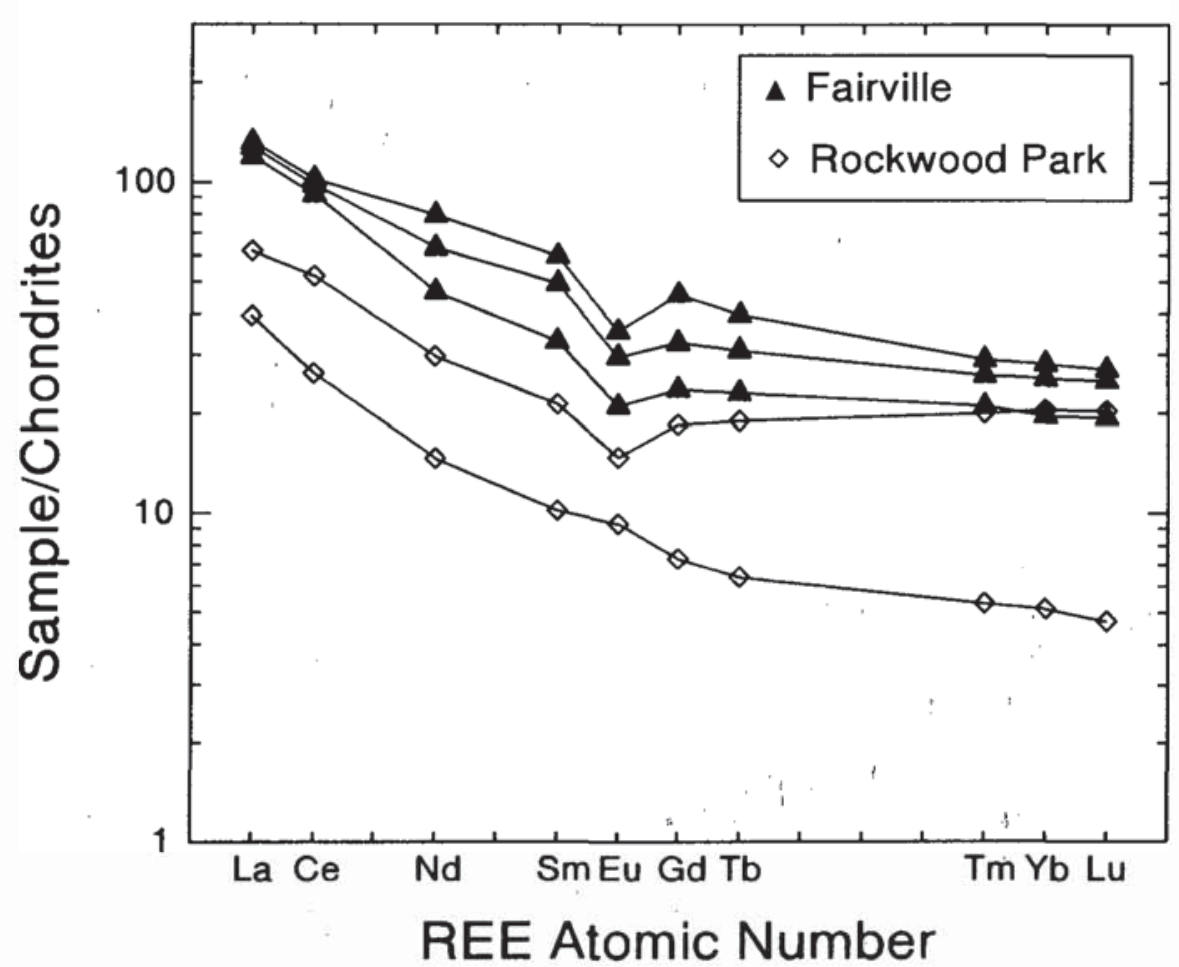

Fig. 9. Chondrite normalized REE plots.

Fig. 7. (a) $\mathrm{Ba}$ and $\mathrm{Sr}$ (ppm) versus Eu/Eu*. Fractionation vectors equal $20 \%$ crystallization. Partition coefficients used in calculations are for intermediate compositions, except as noted, tabulated in Henderson (1982). $\mathrm{Hb}=$ hornblende, $\mathrm{P}=\mathrm{plagioclase}, \mathrm{AF}=$ alkali feldspar, $\mathrm{P}_{\mathrm{r}}=$ plagioclase partition coefficients for rhyolite. See Figure 2 for symbols. FG = Fairville granite, LL = Ludgate Lake, $\mathrm{LP}=$ Lingley pluton, $\mathrm{ML}=$ Mayflower Lake, $\mathrm{PW}=$ Prince of Wales, $\mathrm{RP}=$ Renforth pluton. (b) $\mathrm{Nb}$ and $\mathrm{Zr}$ (ppm) versus Eu/ Eu*. 
EBY AND CURRIB

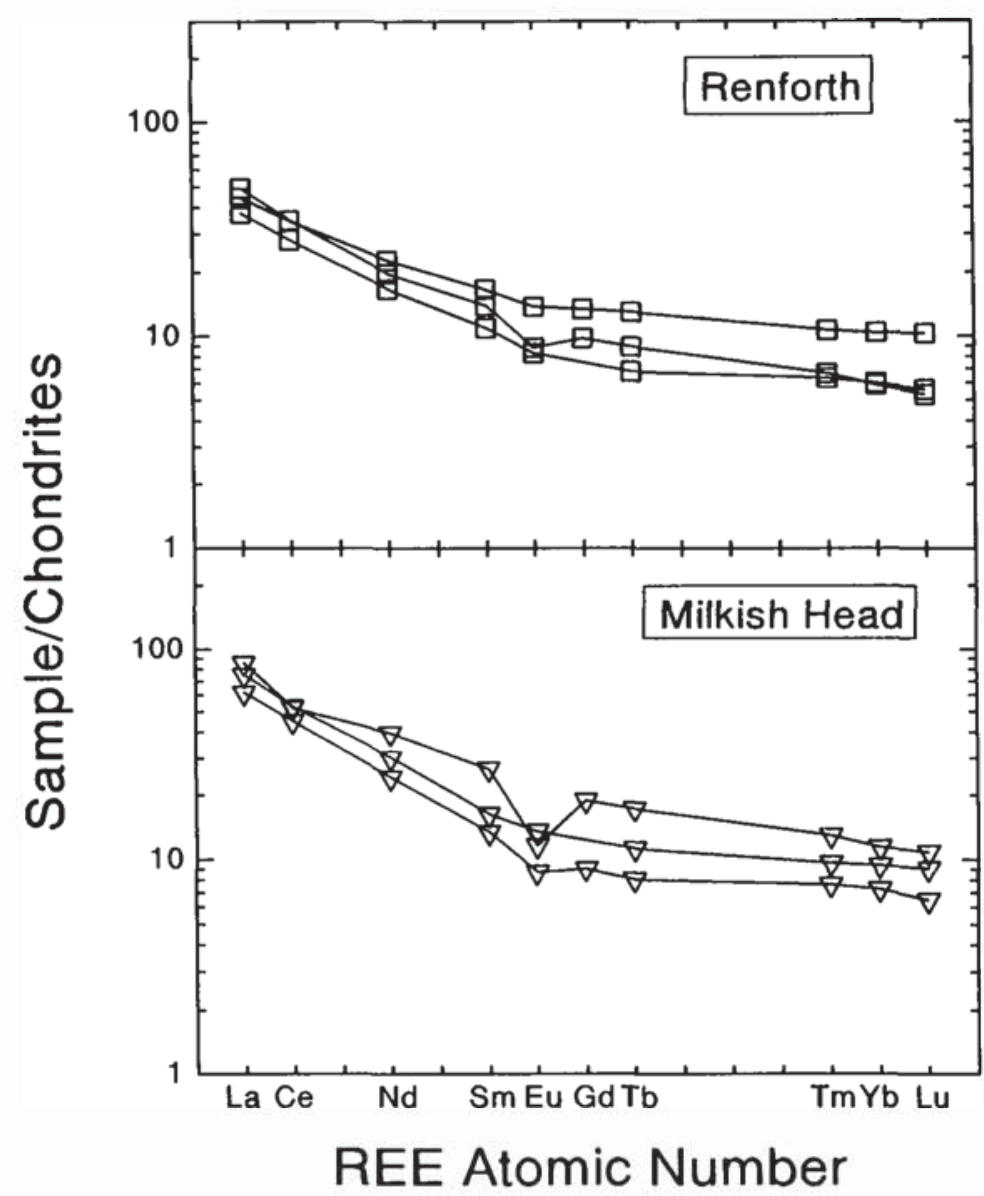

Fig. 10. Chondrite normalized REE plots.

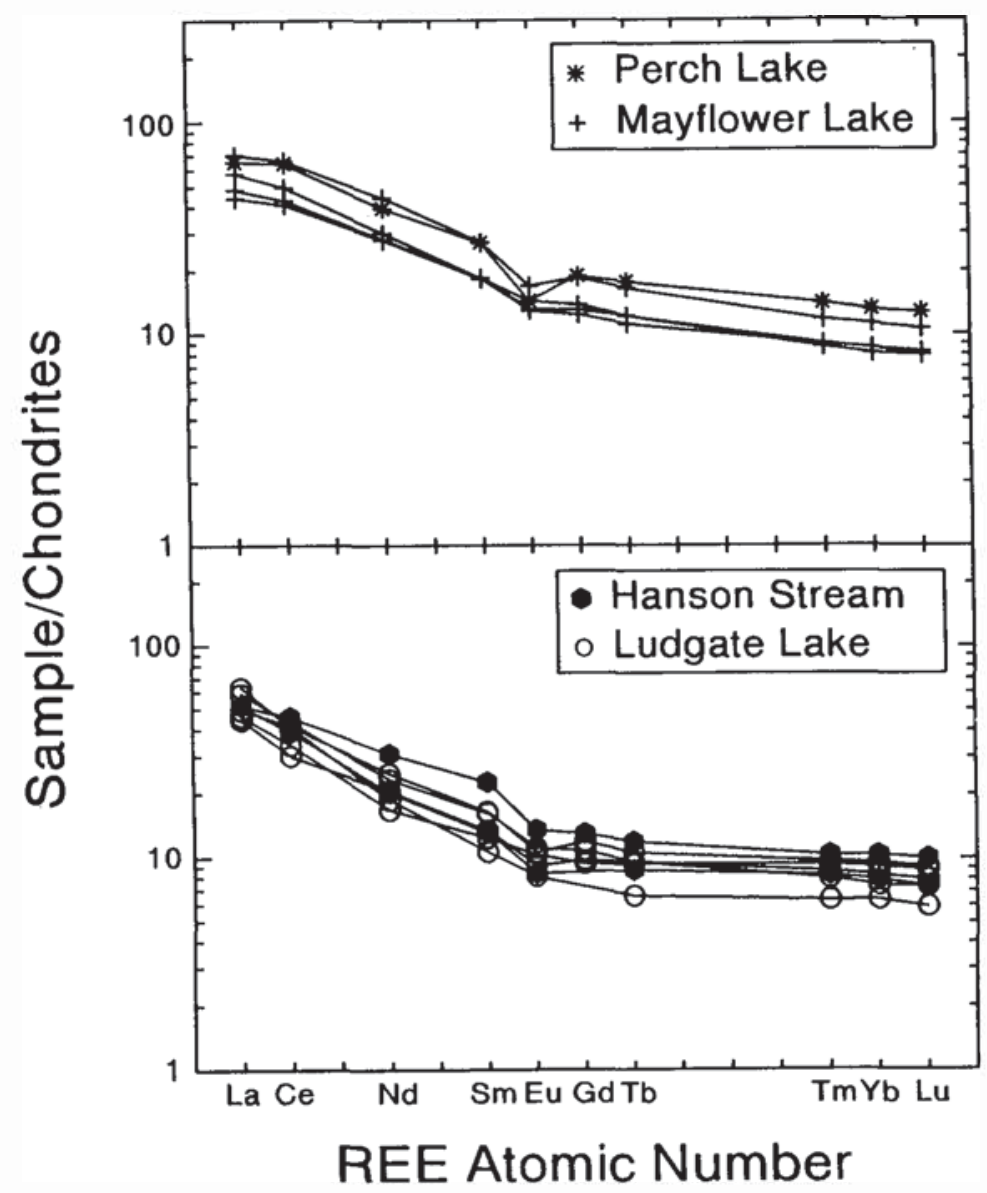

Fig. 11. Chondrite normalized REE plots. 


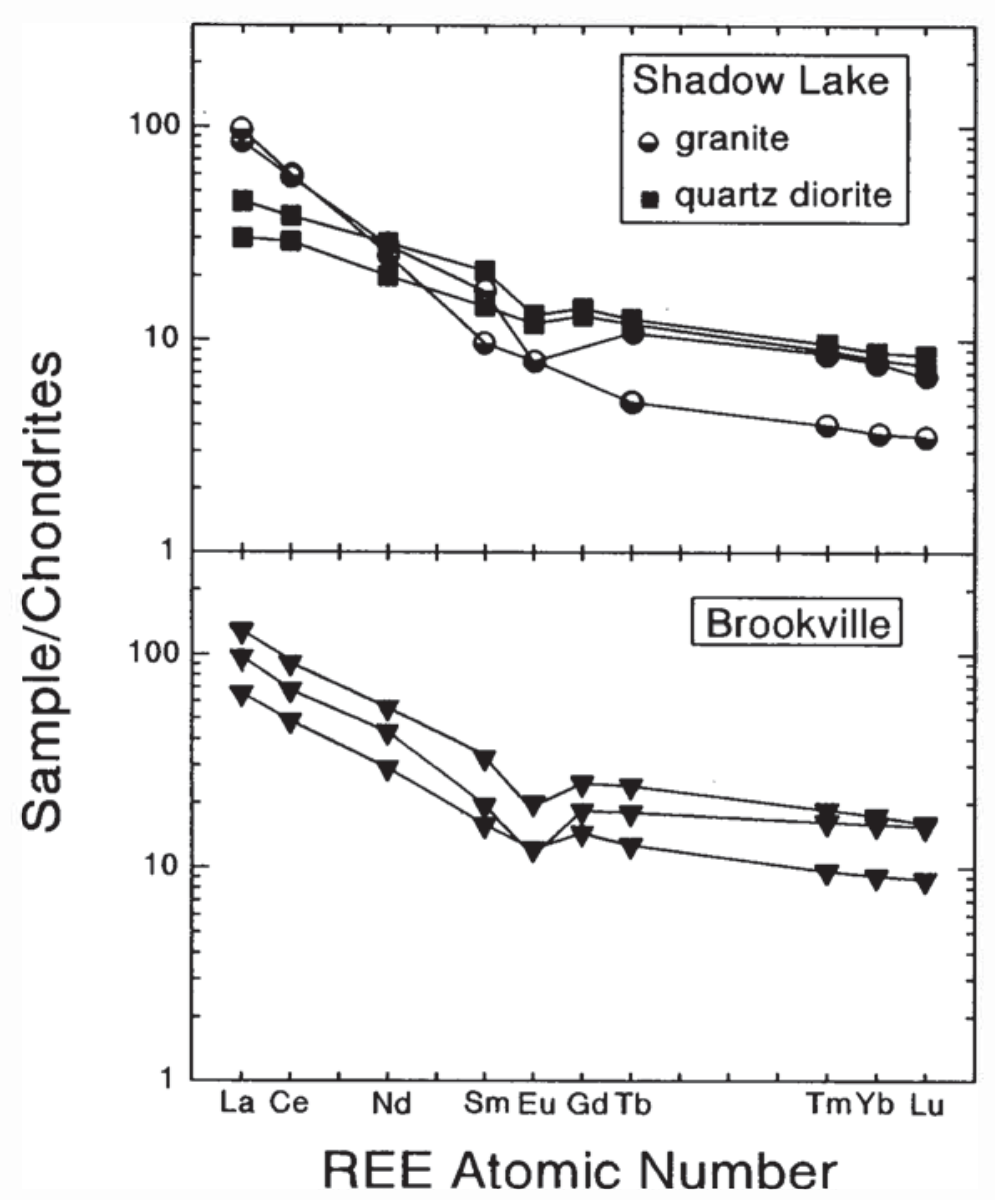

Fig. 12. Chondrite normalized REE plots.

Ar ages. The consequences of the younger Ar/Ar ages representing intrusive ages are considered in the model developed below.

Relative to bulk crust, all of the plutons show Ti depletion (Fig. 13). Many of the samples are also depleted in $\mathrm{Sr}$ and $\mathrm{Ba}$ which reflects feldspar crystallization. While the Brookville Gneiss is chemically broadly similar to the plutons (Fig. 13), its normalized $\mathrm{Ta}$ and $\mathrm{Nb}$ are essentially the same as or slightly less than bulk crust, whereas in a number of the plutons normalized Ta tends to be less than normalized $\mathrm{Nb}$.

On standard granitoid discriminant diagrams (Fig. 14a, b), most of the plutons (and the Brookville Gneiss) plot in the syn-collisional - volcanic arc and I-type fields. The Lingley, Harvey Hill, and Fairville fall into the Within Plate and Atype fields and the Prince of Wales plots on the boundary. The Harvey Hill and Lingley in particular have many of the characteristics of A-type granitoids (see Eby, 1990, for a review). These A-type granitoids would be classified as $\mathrm{A}_{2}$ using the scheme of Eby (1992). Granitoids which fall in this subtype usually occur in post-subduction - post-collisional environments. It is also possible that the Fairville, Lingley, and Harvey Hill are fractionated I-type granitoids. This is an ambiguity in the definition of A-type granites, which has not yet been satisfactorily resolved. On the basis of existing geochronology, the Harvey Hill Pluton is significantly younger than the Fairville or Lingley plutons.
The Bonnell Brook Pluton of the Caledonia terrane consists mainly of syenogranite with a body of dioritic rocks forming the southern part. $\mathrm{A} \mathrm{U} / \mathrm{Pb}$ zircon age of $550 \pm 1 \mathrm{Ma}$ (Bevier and Barr, 1990) has been determined for the syenogranite. The Bonnell Brook syenogranite plots with the Fairville and Lingley plutons on the granitoid discriminant diagrams (Fig. 14), and has A2-type characteristics. Given the U/Pb zircon age of $548 \mathrm{Ma}$ for the Fairville and the inferred age of $555 \mathrm{Ma}$ for the Lingley (Table 1), these granitoids are both chemically and geochronologically similar. If they do represent the same igneous event, then it would appear that the Caledonia, Brookville, and Mascarene terranes had been amalgamated by $\mathrm{ca} .550 \mathrm{Ma}$.

Whalen et al. (1994) report $\mathrm{Nd}, \mathrm{Pb}$ and $\mathrm{O}$ isotopic data for a limited number of Brookville terrane plutons. They conclude that the isotopic data suggest a significant crustal component for these magmas and, given the I-type character of the granitoids, that this component was most likely volcanic. The chemical characteristics of the mafic end member are unknown, but a nearby coeval period of basaltic magmatism (Coldbrook Group; 560-550 Ma; Barr et al., 1994) provides a possible analogue. This magmatism has been interpreted as occurring in a continental arc (Currie and Eby, 1990) or rifted arc (Barr and White, 1988; Barr et al., 1994) setting, and the magmas have chemical characteristics typical of continental margin basalts. Ratios involving immobile elements, selected on the basis of their relative constancy with 


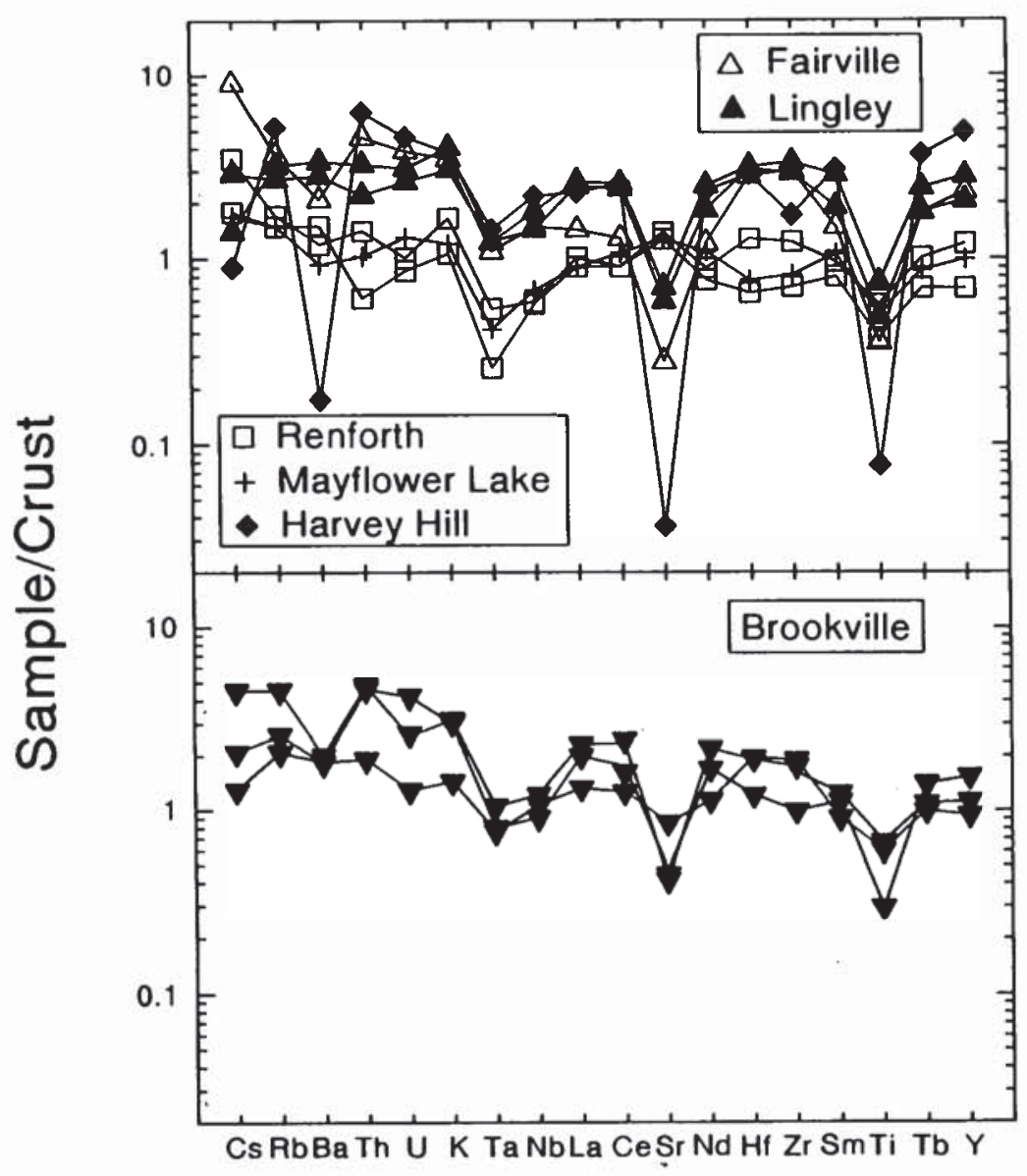

Fig. 13. Representative spider plots for selected Brookville terrane plutons compared to Brookville gneiss. Spider diagrams normalized to bulk crust (Taylor and McLennan, 1985).

respect to fractional crystallization, may fingerprint source regions and contaminants. Several of these ratio plots are shown in Figures 15 and 16. The mafic plutons of the Brookville terrane tend to fall in the same field as the Coldbrook basalts whereas, with one exception, all of the Brookville Gneiss samples plot outside this field. The Brookville Gneiss also has smaller $\mathrm{Nb}$ and $\mathrm{Ta}$ depletions, relative to the plutons. This suggests that continental margin basaltic magma is a more significant component in the plutons than Brookvillelike crust. Projection of $\mathrm{Nb}$ concentrations to unfractionated compositions (Fig. 7b) indicates that the least evolved magmas had very low $\mathrm{Nb}$ content (3-4 ppm). These values are similar to those obtained for continental margin basalts (Thorpe et al., 1984; Hickey et al., 1986). The remainder of the plutons fall in an array extending toward bulk crust (Fig. 15) or in a broad band extending away from both the Coldbrook field and bulk crust (Fig. 16). The latter observation suggests that if Brookville terrane plutons originate by contamination of Coldbrook-like, mantle-derived magma by continental crust, differentiation or alteration processes led to significant increases in $\mathrm{Ce}$ and $\mathrm{Th}$ contents relative to $\mathrm{Nb}$.

Magmatism typical of a continental margin subduction zone occurred in the Caledonia terrane from ca. 635 to 600 Ma. Igneous activity associated with the Brookville Gneiss (orthogneiss) occurred ca. $605 \mathrm{Ma}$. While these events overlap in time, there are significant chemical and geologic differences between the two terranes which indicate that they were not amalgamated at this time. The subsequent period of younger (ca. 560-550 Ma) magmatism in the Caledonia terrane ended with the emplacement of an A-type pluton (Bonnell Brook). Other similar A-type plutons of the same age were emplaced in the Brookville and Mascarene terranes, suggesting that these terranes may have been amalgamated by $550 \mathrm{Ma}$. Magmatism commenced in the Brookville terrane ca. 550 $\mathrm{Ma}$ and may have continued until ca. $520 \mathrm{Ma}$. The plutons emplaced during the earlier part of this period, with the exception of the Fairville, had chemical characteristics typical of continental margin magmatism. Based on present data, this period of Brookville magmatism ended with the emplacement of several A-type plutons (Harvey Hill and Prince of Wales). Whalen et al. (1994) report isotopic data which suggest significant differences between Caledonia and Brookville basement. Thus it is possible that the Caledonia-Brookville terrane boundary represents a juxtaposition of two different pieces of basement, and that this boundary served as a locus for a new period of subduction, as suggested by the chemistry of the Brookville terrane plutons. In this model, the period of subduction ended ca. $520 \mathrm{Ma}$ with late stage extension and emplacement of A-type plutons. 

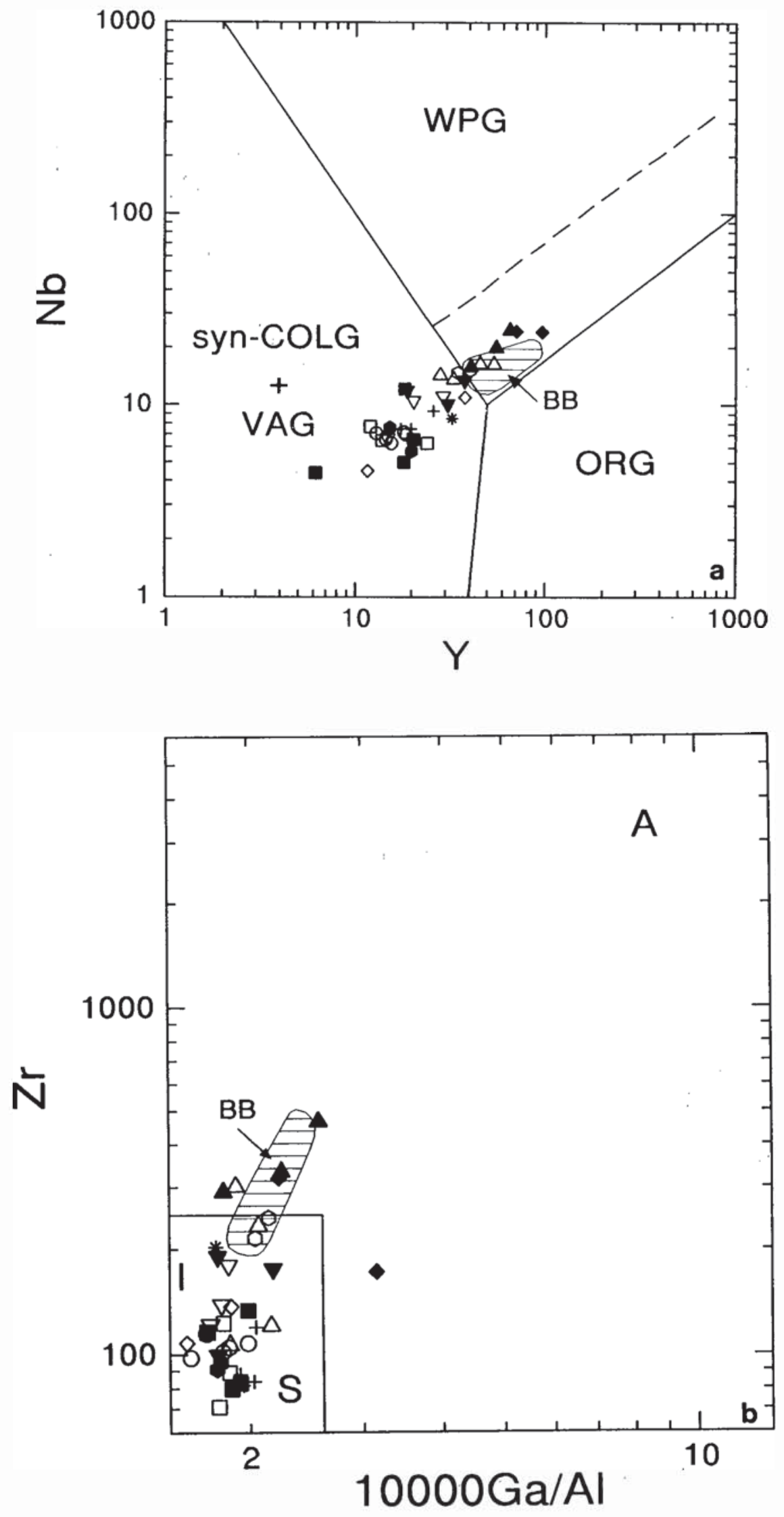

Fig. 14. (a) Y-Nb granitoid discriminant diagram (Pearce et al., 1984). Most of the samples plot in the syn-collisional - volcanic arc field. Fairville, Harvey Hill, Lingley and Prince of Wales plot in the within plate field or on the boundary of this field. See Figure 2 for symbols. $\mathrm{BB}=$ Bonnell Brook pluton of the Caledonia terrane. (b) $10000 \mathrm{Ga} / \mathrm{Al}-\mathrm{Zr}$ granitoid discriminant diagram (Whalen et al., 1987). Most of the samples plot in the I\&S field, but Fairville, Harvey Hill and Lingley plot in the A-type granitoid field. 


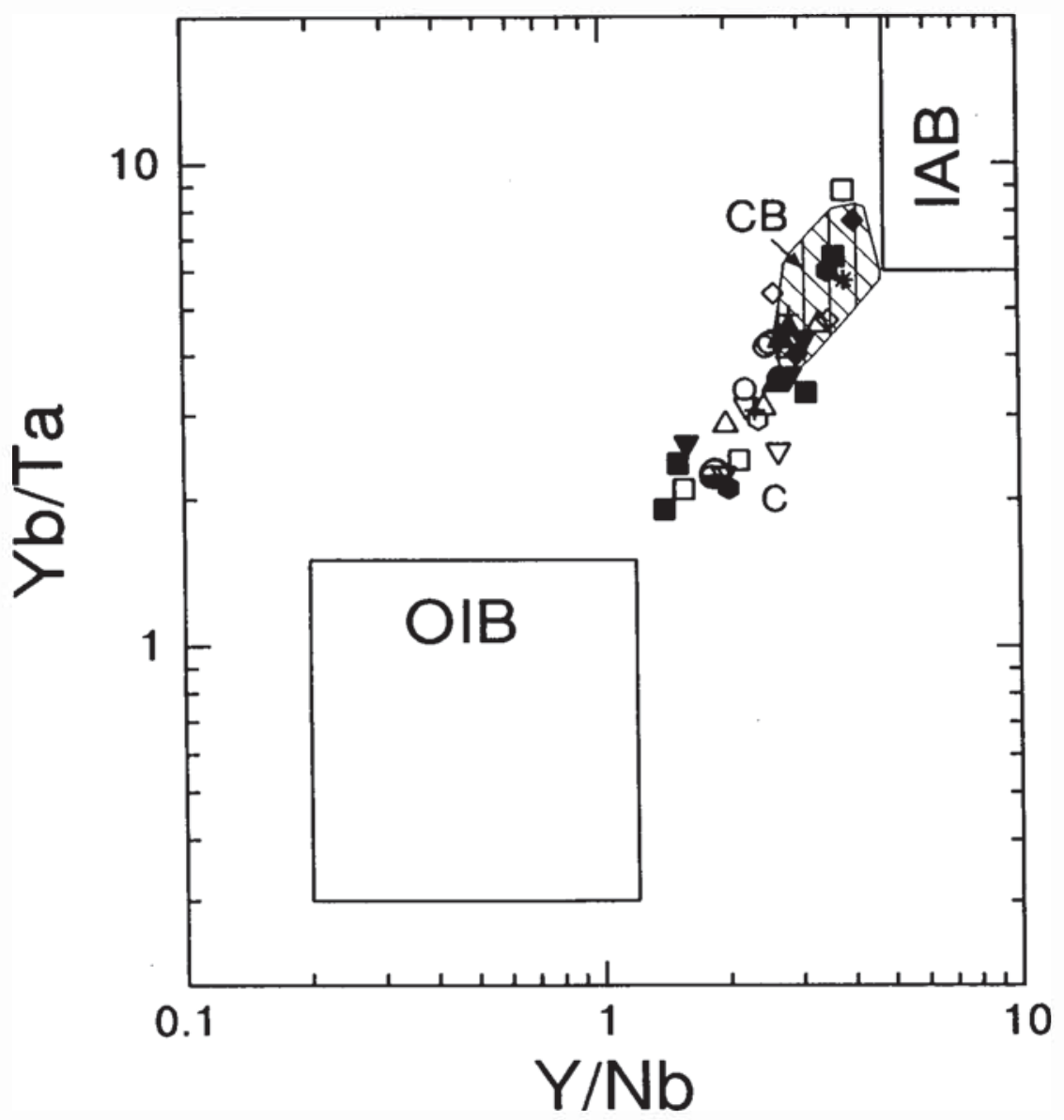

Fig. 15. Y/Nb-Yb/Ta discriminant diagram (Eby, 1990). Mafic lithologies plot in the same field as the Coldbrook basalts (CB), while more felsic units plot in an array towards bulk continental crust (C). Data for Coldbrook basalts from Currie and Eby (1990). See Figure 2 for symbols.

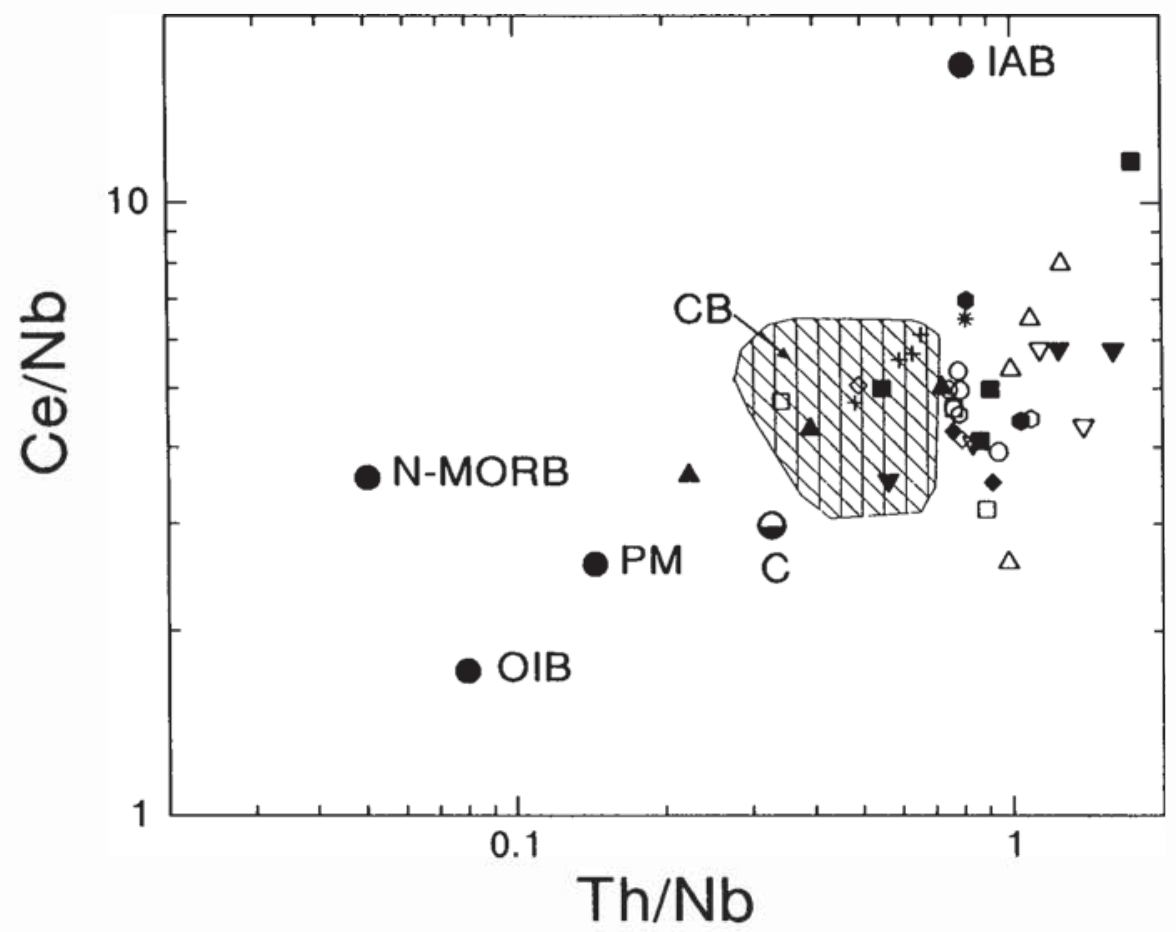

Fig. 16. Th/Nb-Ce/Nb plot. Mafic lithologies plot in the Coldbrook basalt field with the more felsic samples scattering away from bulk crust towards higher Th/Nb ratios. IAB (calcalkaline island arc basalt, Sun, 1980), N-MORB (Hofmann, 1988) and PM and OIB (Sun and McDonough, 1989). See Figure 2 for symbols. 


\section{Conclusions}

(1) Mafic plutons of the Brookville terrane were derived from a source similar to that of the continental margin basalts of the Coldbrook Group of the Caledonia terrane, and some sialic plutons appear to be derived from mixtures of this basaltic component and a component similar to bulk crust.

(2) For most major elements, samples from individual plutons form smooth curves on Harker diagrams, suggesting that mafic and sialic members are connected by igneous differentiation of a magma similar to the basaltbulk crust mixture noted in point 1 . If this is correct, differentiation produced an unusual increase in $\mathrm{Th} / \mathrm{Nb}$ and $\mathrm{Ce} / \mathrm{Nb}$ ratios, due either to further depletion of already very low $\mathrm{Nb}$ contents or increase in Th and Ce. Trace element modelling indicates that magma evolution was controlled by the fractionation of hornblende, plagioclase and alkali feldspar.

(3) The presence of A2-type granitoids of similar age in the Caledonia, Brookville, and Mascarene terranes suggests that these terranes had been amalgamated by ca. 550 Ma.

(4) Given the existing geochronology and chemical data, a possible model is that following amalgamation of the Brookville and Caledonia terranes at $550 \mathrm{Ma}$, another period of subduction commenced as evidenced by the emplacement of plutons into the Brookville terrane, which have characteristics typical of continental margin magmatism. In this model, the period of subduction ended with extension and emplacement of A-type plutons.

\section{ACKNOWLEDGEMENTS}

Trace element XRF data were obtained at Oxford University and the assistance of $\mathrm{K}$. Parish (Oxford) is gratefully acknowledge. Neutron activation analyses were done at the University of Massachusetts-Lowell Radiation Laboratory. C. White was involved in an earlier version of the manuscript, and his contributions to the manuscript are gratefully acknowledged. The authors however are solely responsible for the interpretations reported herein, some of which do not have universal acceptance. Drs. A. Kerr and D. Kontak are thanked for their thorough and helpful reviews of the manuscript.

BARR, S.M. and RAEside, R.P. 1989. Tectonostratigraphic terranes in Cape Breton Island, Nova Scotia: implications for configuration of the northern Appalachian orogen. Geology, 7, pp. 822-825.

BARR, S.M. and White, C.E. 1988. Petrochemistry of contrasting late Precambrian volcanic and plutonic associations, Caledonia Highlands, southern New Brunswick. Maritime Sediments and Atlantic Geology, 24, pp. 353-372.

.-.- 1989. Re-interpretation of Precambrian stratigraphy, Kings and Saint John Counties, New Brunswick. New Brunswick Department of Natural Resources and Energy, Mineral and Energy Division, Information Circular 89-2, pp. 182-189. 1991. Revised stratigraphy of the Avalon Terrane of south- ern New Brunswick. In Geology of the coastal lithotectonic block and neighboring terranes, eastern Maine and southern New Brunswick. Edited by A. Ludman. Eighty-third New England Intercollegiate Geological Conference, pp. 1-12.

..-.- 1996. Contrasts in late Precambrian-early Paleozoic tectonothermal history between Avalon Composite Terrane sensu stricto and other peri-Gondwanan terranes in southern New Brunswick and Cape Breton Island, Canada. In Avalonian and related peri-Gondwanan terranes of the Circum-North Atlantic. Edited by R.D. Nance and M.D. Thompson. Geological Society of America Special Paper 304, pp. 95-108.

BARR, S.M., Bevier, M.L., White, C.E., and Doig, R. 1994. Magmatic history of the Avalon terrane of southern New Brunswick based on U-Pb (zircon) geochronology. Journal of Geology, 102 , pp. 399-409.

Bernas, B. 1968. A new method for decomposition and comprehensive analysis of silicates by atomic absorption spectrometry. Analytical Chemistry, 40, pp. 1682-1686.

Bevier, M.L. and BARR, S.M. 1990. U-Pb age constraints on the stratigraphy and tectonic history of the Avalon terrane, New Brunswick. Journal of Geology, 98, pp. 53-63.

Bevier, M.L., White, C.E., and BarR, S.M. 1990. Late Precambrian ages for the Brookville Gneiss, southern New Brunswick. Journal of Geology, 98, pp. 955-965.

---- 1991. A new U-Pb date for the French Village quartz diorite, Saint John County, southern New Brunswick. In Project Summaries for 1991, Sixteenth Annual Review of Activities. Edited by S.A. Abbott. New Brunswick Department of Natural Resources and Energy, Minerals and Energy Division, Information Circular 91-2, pp. 195-198.

Currie, K.L. 1984. A reconsideration of some geological relations near Saint John, New Brunswick. Geological Survey of Canada, Paper 84-1A, pp. 193-201.

--.-. 1987. Late Precambrian igneous activity and its tectonic implications; Musquash-Loch Alva region, southern New Brunswick. Geological Survey of Canada, Paper 87-1A, pp. 663-671.

CURrie, K.L. and EBY, G.N. 1990. Geology and geochemistry of the late Precambrian Coldbrook Group near Saint John, New Brunswick. Canadian Journal of Earth Sciences, 27, pp. 1418 1430.

Currie, K.L. and Hunt, P.A. 1991. Latest Precambrian igneous activity near Saint John, New Brunswick. Geological Survey of Canada, Radiometric and Isotopic Studies: Report 5, Paper 91-2, pp. 11-17.

Dallmeyer, R.D., Doig, R., Nance, R.D., and Murphy, J.B. 1990. ${ }^{40} \mathrm{Ar} /{ }^{39} \mathrm{Ar}$ and $\mathrm{U}-\mathrm{Pb}$ mineral ages from the Brookville Gneiss and Green Head Group: implications for terrane analysis and evolution of Avalonian "basement" in southern New Brunswick. Maritime Sediments and Atlantic Geology, 26, pp. 247-258.

DAllmeYER, R.D. and NANCE, R.D. 1992. Tectonic implications of ${ }^{40} \mathrm{Ar} /{ }^{39} \mathrm{Ar}$ mineral ages from late Precambrian-Cambrian plutons, Avalon composite terrane, southern New Brunswick, Canada. Canadian Journal of Earth Sciences, 29, pp. 24452462.

Dickson, W.L. 1983. Geology, geochemistry, and petrology of the Precambrian and Carboniferous igneous rocks between Saint John and Beaver Harbour, southern New Brunswick. Ph.D. thesis, University of New Brunswick, Fredericton, New Brunswick, 409 p.

Doig, R., Nance, R.D., Murphy, J.B., and Casseday, R.P. 1990. Evidence for Silurian sinistral accretion of Avalon composite terrane in Canada. Journal of the Geological Society, London, 147, pp. 927-930. 
EBY, G.N. 1990. The A-type granitoids: a review of their occurrence and chemical characteristics and speculations on their petrogenesis. Lithos, 26, pp. 115-134.

-1992. Chemical subdivision of the A-type granitoids: petrogenetic and tectonic implications. Geology, 20, pp. 641-644.

EBY, G.N. and CURRIE, K.L. 1993. Petrology and geochemistry of the Kingston complex - a bimodal sheeted dyke suite in southern New Brunswick. Atlantic Geology, 29, pp. 121-135.

FYFFE, L.R. and FriCKeR, A. 1987. Tectonostratigraphic terrane analysis of New Brunswick. Maritime Sediments and Atlantic Geology, 23, pp. 113-122.

Hayes, A.O. and Howell, G.G. 1937. Geology of Saint John, New Brunswick. Geological Society of America, Special Paper $5,146 \mathrm{p}$.

Henderson, P. 1982. Inorganic Geochemistry. Pergamon Press Limited, Oxford, 353 p.

HICKEY, R.L., FrEY, F.A., and GeRLACH, D.C. 1986. Multiple sources for basaltic arc rocks from the southern volcanic zone of the Andes $\left(34-41^{\circ} \mathrm{S}\right)$ : trace element and isotopic evidence for contributions from subducted oceanic crust, mantle and continental crust. Journal of Geophysical Research, 91, pp. 5963-5983.

Hofiman, A.W. 1988. Chemical differentiation of the Earth: the relationship between mantle, continental crust, and oceanic crust. Earth and Planetary Science Letters, 90, pp. 297-314.

Keppie, J.D., Nance, R.D., Murphy, J.B., and Dostal, J. 1991. Northern Appalachians; Avalon and Meguma Terranes. In The West African Orogens and Circum-Atlantic Correlatives. Edited by R.D. Dallmeyer and J.P. Laroche. Springer-Verlag, Berlin, pp. 315-333.

McLeod, M.J., Johnson, S.C., and Ruitenberg, A.A. 1994. Geological map of southern New Brunswick. New Brunswick Department of Natural Resources and Energy, Mineral Resources, Maps NR-5 and NR-6.

Nakamura, N. 1974. Determination of REE, Ba, Fe, Mg, Na and $\mathrm{K}$ in carbonaceous and ordinary chondrites. Geochimica et Cosmochimica Acta, 38, pp. 757-775.

NANCE, R.D. and Dallmeyer, R.D. $1993 .{ }^{40} \mathrm{Ar} /{ }^{39} \mathrm{Ar}$ amphibole ages from the Kingston Complex, New Brunswick: evidence for Silurian-Devonian tectonothermal activity and implications for the accretion of the Avalon composite terrane. Journal of Geology, 101, pp. 375-388.

..... 1994. Structural and ${ }^{40} \mathrm{Ar} /{ }^{39} \mathrm{Ar}$ mineral age constraints for the tectonothermal evolution of the Green Head Group and Brookville Gneiss, southern New Brunswick, Canada; implications for the configuration of the Avalon composite terrane. Geological Journal, 29, pp. 293-322.

Pearce, J.A., Harris, N.B.W., and Tindle, A.G. 1984. Trace element discrimination diagrams for the tectonic interpretation of granitic rocks. Journal of Petrology, 25, pp. 956-983.

Streckeisen, A. 1976. To each plutonic rock its proper name. Earth Science Reviews, 12, pp. 1-23.

Sun, S.S: 1980. Lead isotopic study of young volcanic rocks from mid-ocean ridges, ocean islands and island arcs. Philosophical Transactions of the Royal Society of London, A297, pp. 409445:
Sun, S.S. and McDonough, W.F. 1989. Chemical and isotopic systematics of oceanic basalts: implications for mantle composition and processes. In Magmatism in the Ocean Basins. Edited by A.D. Saunders and M.J. Norry. Geological Society, Special Publication 42, pp. 313-345.

TANOLI, S.K. and PICKeRILL, R.K. 1988. Lithostratigraphy of the Cambrian-Lower Ordovician Saint John Group, southern New Brunswick. Canadian Journal of Earth Sciences, 25, pp. 669 690.

TAYLOR, S.R. and McLennan, S.M. 1985. The Continental Crust: its Composition and Evolution. Blackwell Scientific Publications, Oxford, 312 p.

Thorpe, R.S., Francis, P.W., and O'Callaghan, L. 1984. Relative roles of source composition, fractional crystallization and crustal contamination in the petrogenesis of Andean volcanic rocks. Philosophical Transactions of the Royal Society of London, A310, pp. 675-692.

TutTle, O.F. and Bowen, N.L. 1958. Origin of granite in the light of experimental studies in the system $\mathrm{NaAlSi}_{3} \mathrm{O}_{8}-\mathrm{KAISi}_{3} \mathrm{O}_{8}$ $\mathrm{SiO}_{2}-\mathrm{H}_{2} \mathrm{O}$. Geological Society of America, Memoir 74, 153 p.

Whalen, J.B., Currie, K.L., and Chappell, B.W. 1987. A-type granites: geochemical characteristics, discrimination and petrogenesis. Contributions to Mineralogy and Petrology, 95, pp. 407-419.

Whalen, J.B., Jenner, G.A., Currie, K.L., Barr, S.M., Longstaffe, F.J., and HeGNer, E. 1994. Geochemical and isotopic characteristics of granitoids of the Avalon Zone, southern New Brunswick: Possible evidence for repeated delamination events. Journal of Geology, 102, pp. 269-282.

White, C.E. 1995. Geology, geochronology, and tectonic evolution of the Brookville terrane, southern New Brunswick. Ph.D. thesis, Dalhousie University, Halifax, Nova Scotia, $513 \mathrm{p}$.

White, C.E. and BARR, S.M. 1996. Geology of the Brookville terrane, southern New Brunswick, Canada. In Avalonian and related peri-Gondwanan terranes of the Circum-North Atlantic. Edited by R.D. Nance and M.D. Thompson. Geological Society of America Special Paper 304, pp. 133-147.

White, C.E., Barr, S.M., Bevier, M.L., and Devenu, K.A. 1990. Field relations, composition, and age of plutonic units in the Saint John area of southern New Brunswick. Atlantic Geology, 26, pp. 259-270.

Williams, H. 1979. Appalachian orogen in Canada. Canadian Journal of Earth Sciences, 16, pp. 792-807.

WiLson, A.D. 1955. A new method for the determination of ferrous iron in rocks and minerals. Bulletin of the Geological Survey of Great Britain, 9, pp. 56-58.

Zain-Eldeen, U., Yan, N., Manuel, L.M., Nance, R.D., Doig, R., and DALLMEYER, R.D. 1991. Late Carboniferous sedimentation and tectonics in the Chance Harbour-Dipper Harbour area, southern New Brunswick, Canada. Geological Society of America, Abstracts with Programs, 23, p. 153.

Editorial Responsibility : G.L. Williams 